Supporting Information

\title{
Mechanogeneration of Acid from Oxime Sulfonates
}

\author{
Chikkannagari Nagamani ${ }^{\dagger, \uparrow}$, Huiying Liu ${ }^{\dagger}$, Jeffrey S. Moore ${ }^{\dagger, \uparrow, *}$ \\ ${ }^{\dagger}$ Department of Chemistry, and ${ }^{\top}$ Beckman Institute for Advanced Science and Technology, \\ University of Illinois at Urbana-Champaign, Urbana, Illinois, 61801, USA
}

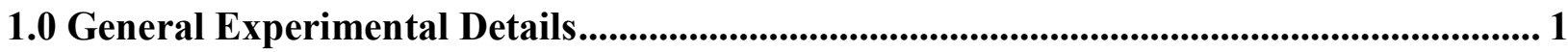

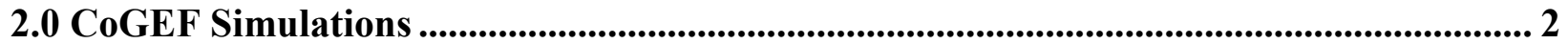

3.0 Ultrasound-induced Mechanochemical Scission of Polymers ......................................... 3

4.0 X-ray Crystal Structure and ${ }^{19}$ F NMR Comparison of the Oxime and Oxime Sulfonate

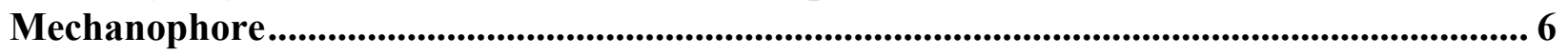

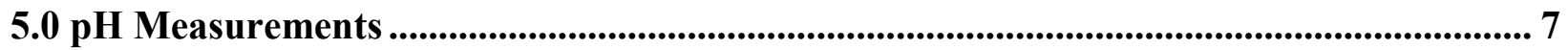

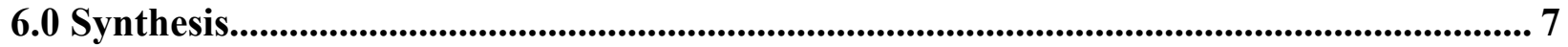

7.0 Polymer Synthesis .............................................................................................................. 14

8.0 X-ray Crystallographic Data ................................................................................................... 15

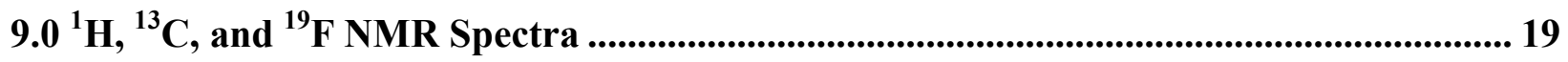

10.0 References ........................................................................................................................... 29

\subsection{General Experimental Details}

All air or moisture-sensitive manipulations were performed under nitrogen atmosphere using standard schlenk techniques. All glassware was oven-dried prior to use. Unless otherwise stated, all starting materials and reagents were purchased from Sigma-Aldrich, Matrix Scientific, or TCI America and used without further purification. HPLC grade acetonitrile was purchased from Fisher Scientific and used without further purification. ${ }^{1} \mathrm{H},{ }^{13} \mathrm{C}$, and ${ }^{19} \mathrm{~F}$ NMR spectra were recorded on Varian Unity $500 \mathrm{MHz}$ spectrometer, and ${ }^{15} \mathrm{~N}$ NMR spectra were recorded on Varian Unity $600 \mathrm{MHz}$ spectrometer in the VOICE NMR laboratory at the University of Illinois. Chemical shifts are reported in $\delta(\mathrm{ppm})$ relative to the residual solvent peak $\left(\left(\mathrm{CDCl}_{3}\right): 7.26\right.$, $\left(\mathrm{CD}_{3}\right)_{2} \mathrm{CO}: 2.05$ for ${ }^{1} \mathrm{H}$; $\left(\mathrm{CDCl}_{3}\right)$ : 77.16, $\left(\mathrm{CD}_{3}\right)_{2} \mathrm{CO}: 29.84$ for $\left.{ }^{13} \mathrm{C}\right) . \mathrm{CFCl}_{3}$ was used as an internal standard for ${ }^{19} \mathrm{~F}$ NMR spectra and ${ }^{19} \mathrm{~F}$ NMR chemical shifts are reported in $\delta(\mathrm{ppm})$ relative to $\mathrm{CFCl}_{3}(\delta=0.00 \mathrm{ppm}) .{ }^{15} \mathrm{~N}$ NMR chemical shifts are reported in $\delta(\mathrm{ppm})$ relative to $\mathrm{CH}_{3} \mathrm{NO}_{2}(\delta$ $=0.00 \mathrm{ppm})$. Coupling constants $(\mathrm{J})$ are reported in Hertz $(\mathrm{Hz})$. Splitting patterns are designated 
as $\mathrm{s}$ ( singlet), $\mathrm{d}$ (doublet), $\mathrm{t}$ (triplet), $\mathrm{q}$ (quartet), dd (doublet of doublets), m (multiplet), and br (broad). ESI and high-resolution ESI mass spectra were recorded on a Micromass 70-VSE spectrometer through the Mass Spectrometry Facility, SCS at University of Illinois. Analytical gel permeation chromatography (GPC) analyses were performed on a system composed of a Waters 515 HPLC pump, a Thermoseparations Trace series AS100 autosampler, a series of three Waters HR Styragel columns (7.8' 300 mm, HR3, HR4, and HR5), and a Viscotek TDA Model 300 triple detector array, in HPLC grade THF (flow rate $=1.0 \mathrm{~mL} / \mathrm{min}$ ) at $30^{\circ} \mathrm{C}$. The GPC was calibrated using a series of monodisperse polystyrene standards. Ultrasound sonication experiments were performed on a Vibra Cell 505 liquid processor with a 1/200 diameter solid horn from Sonics and Materials using either $10 \mathrm{~mL}$ Suslick cell at $25 \%$ amplitude or $50 \mathrm{~mL}$ Suslick cell at 50\% amplitude. The Suslick cells were made by the Glass Shop, SCS, University of Illinois. Neslab CC 100 immersion cooler equipped with a Cryotrol temperature controller was used to maintain a constant temperature bath for sonication experiments.

\subsection{CoGEF Simulations}

CoGEF simulations were performed using Spartan '10 at the B3LYP/6-31G* level of theory following previously reported methods. ${ }^{1-3}$ The oxime sulfonate mechanophore with methyl esters at each end was energy minimized using DFT at the B3LYP $6 \square 31 \mathrm{G}^{*}$ level of theory to obtain the equilibrium geometry and ground state energy. The torsion angles for both the oxime $\left(\mathrm{CF}_{3}\right.$ $\mathrm{C}=\mathrm{N}-\mathrm{O}-)$ bonds were locked to be in a trans-geometry during the ground state energy minimization calculations; the torsion angles, however, were not constrained during the subsequent bond stretching and energy minimization calculations. Starting from the equilibrium geometry, the distance between the methyl esters was artificially constrained by increasing in increments. The energy of the constrained structure at each interval was minimized. The 'S-O'

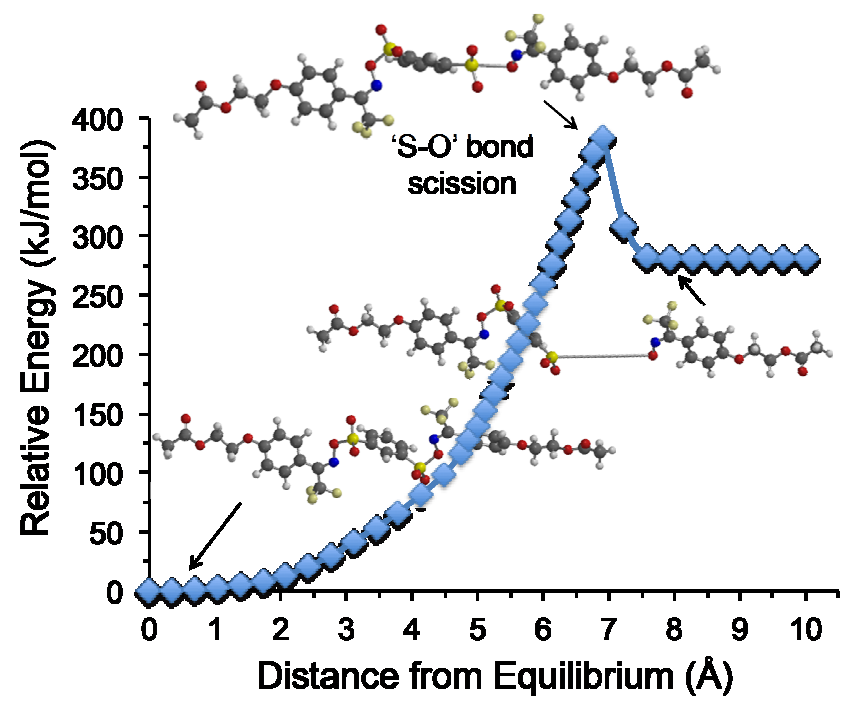

Figure S1. CoGEF simulations for an oxime sulfonate mechanophore indicate selective activation of the 'S-O' bond. 
bond in the oxime sulfonate mechanophore is selectively cleaved after the molecule is elongated $>$ $6.917 \AA$ from equilibrium with a relative bond dissociation energy of ca. $90 \mathrm{kcal} / \mathrm{mol}$. It should be noted that both the left and the right 'S-O' bonds have equal probability for scission since the mechanophore is a symmetric molecule, and whether the left or the right ' $\mathrm{S}-\mathrm{O}$ ' bond breaks is expected to be totally a random process. Although the mechanophore has two 'S-O' bonds, only one of the 'S-O' bonds is expected to break upon force activation because after the first 'S-O' bond scission the other ' $\mathrm{S}-\mathrm{O}$ ' bond will be at the polymer terminus and hence cannot be broken.

\subsection{Ultrasound-induced Mechanochemical Scission of Polymers}

Sonication experiments were performed on a Vibra Cell 505 liquid processor with a 1/200 diameter solid horn from Sonics and Materials using a Suslick cell. A $1 \mathrm{mg} / \mathrm{mL}$ polymer solution dissolved in HPLC grade acetonitrile was sonicated with pulsed ultrasound $(1.0 \mathrm{~s}$ on, $1.0 \mathrm{~s}$ off, $8.7 \mathrm{~W} \mathrm{~cm}^{-2}$ ) under argon atmosphere at $6-9{ }^{\circ} \mathrm{C}$. Constant temperature was maintained through out the experiment using an immersion cooler equipped with a Cryotrol temperature controller.

For GPC Analyses: Aliquots of ultrasonicated polymer solutions were removed at regular time intervals and the solution was dried under a nitrogen stream. The samples were then redissolved in THF to afford a $2 \mathrm{mg} / \mathrm{mL}$ solution, filtered through a $0.45 \square \mathrm{m}$ PTFE syringe filter, and analyzed by GPC. The rate constants of polymer cleavage $\left(k^{\prime}\right)$ for polymer $\mathbf{1}$ and PMA control (Figure 1) were calculated from the slope of the least squares linear regression of the data according to the method of Kryger et $a l^{3}{ }^{3}$ using equation 1 , where $M_{\mathrm{t}}$ is the number average molecular weight $\left(M_{\mathrm{n}}\right)$ of the sonicated sample at time $\mathrm{t}, M_{\mathrm{i}}$ is the initial number average molecular weight of the polymer, and $k^{\prime}$ is the rate constant of polymer cleavage adjusted for the molecular weight of the monomer unit, $\mathrm{M}_{0}\left(k^{\prime}=k / \mathrm{M}_{0}\right)$.

$$
\frac{1}{M_{t}}-\frac{1}{M_{i}}=k^{\prime} \mathrm{t}
$$

For polymer end-group analyses using ${ }^{19} \mathbf{F}$ NMR: Ultrasonicated polymer solutions in acetonitrile were thoroughly dried under vacuum and then redissolved in $\mathrm{CDCl}_{3}$ containing $\mathrm{CFCl}_{3}$ as an internal standard for ${ }^{19} \mathrm{~F}$ NMR analyses.

For ${ }^{15} \mathrm{~N}$ NMR: Due to low sensitivity of ${ }^{15} \mathrm{~N}$ NMR as well as low concentration of ${ }^{15} \mathrm{~N}$ atoms per polymer chain, gel phase NMR was used to record ${ }^{15} \mathrm{~N}$ NMR.${ }^{4} 400 \mathrm{mg}$ of polymer sample dissolved in about $0.5 \mathrm{~mL} \mathrm{CDCl} 3$ was used to record ${ }^{15} \mathrm{~N} \mathrm{NMR}$. 

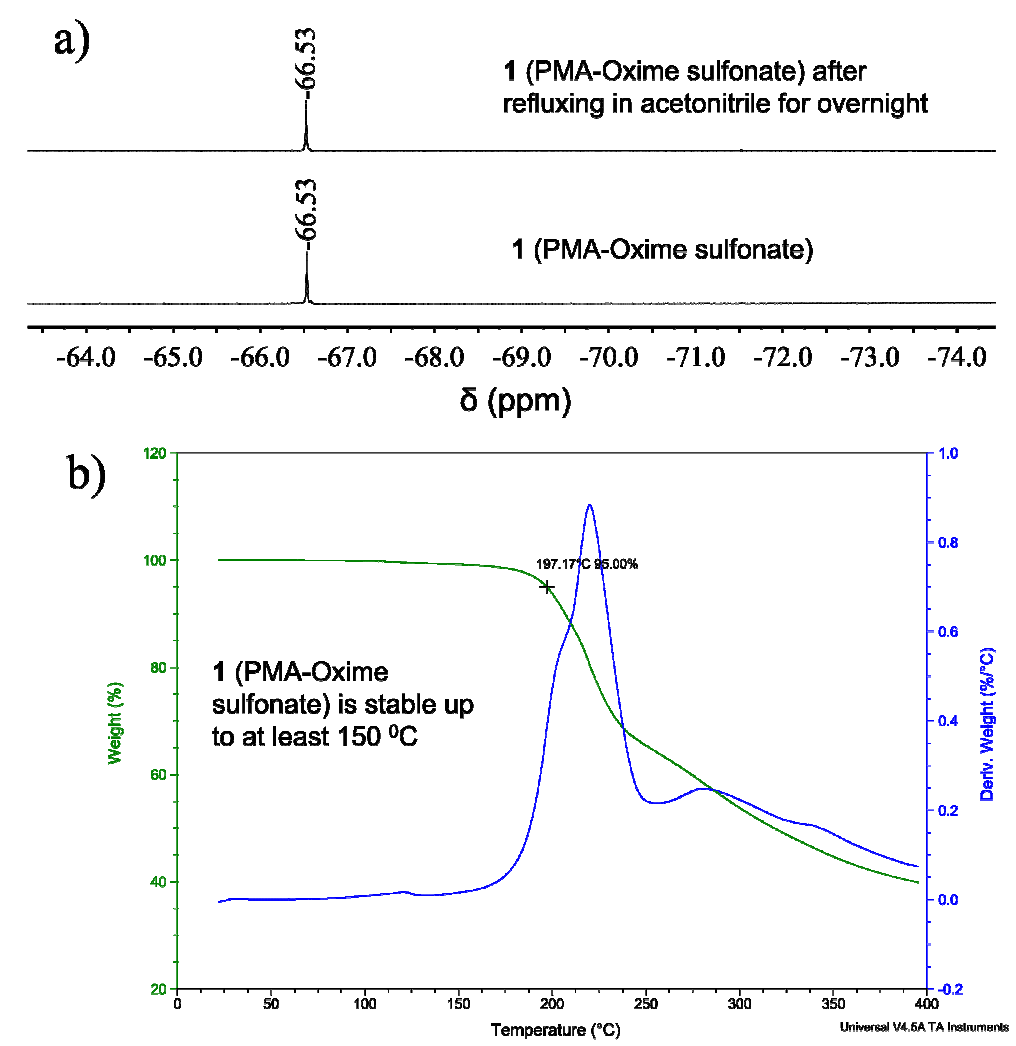

Figure S2. Thermal stability of polymer $\mathbf{1}$ in solution and solid-state. To determine solution-state thermal stability, polymer 1 was refluxed in acetonitrile for overnight, vacuum dried, and ${ }^{19} \mathrm{~F}$ NMR spectra before and after refluxing were recorded. Thermogravimetric analysis $\left(10{ }^{0} \mathrm{C} / \mathrm{min}\right.$ heating rate) was performed to determine the solid-state stability of polymer 1.

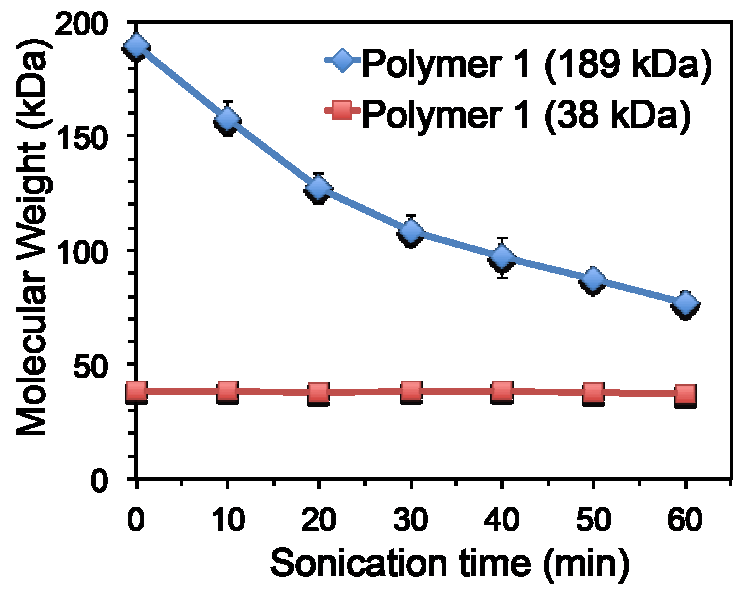

Figure S3. Reduction in polymer molecular weight $\left(M_{\mathrm{n}}\right)$ with sonication time. Measurements were performed in triplicate, and the error bars represent standard deviation at each data point. 




Figure S4. ${ }^{19} \mathrm{~F}$ NMR spectra of polymer 1 before and after sonication. $\mathrm{CFCl}_{3}(\delta=0 \mathrm{ppm})$ was used as an internal standard.

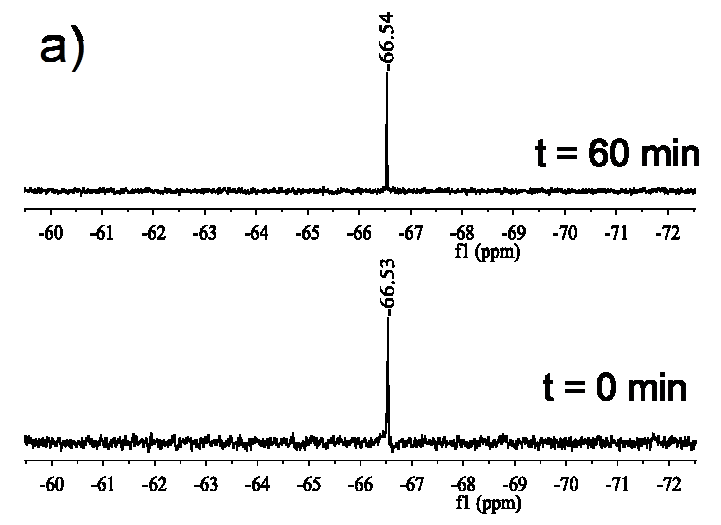

b)
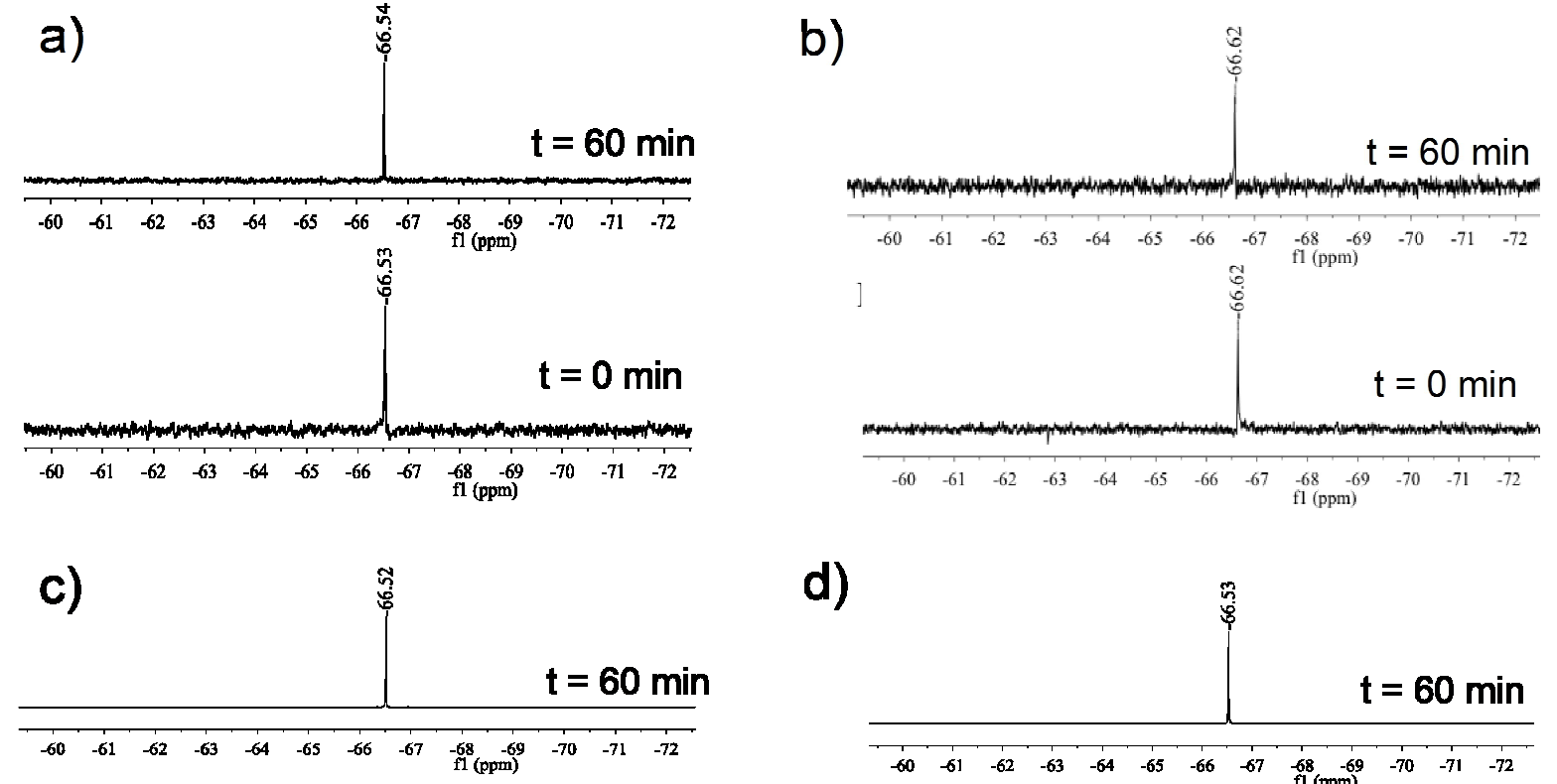

d)

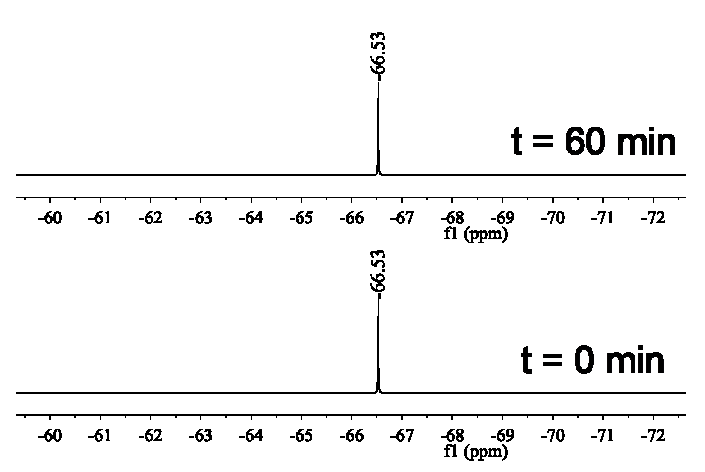

Figure S5. ${ }^{19} \mathrm{~F}$ NMR spectra before and after sonication. (a) polymer $\mathbf{1}_{\text {low }}$ Mw $(38.2 \mathrm{kDa})$; (b) polymer 2; (c) bifunctional initiator 5; (d) a physical mixture of 5 and PMA polymer. $\mathrm{CFCl}_{3}(\delta=0 \mathrm{ppm})$ was used as an internal standard. 


\subsection{X-ray Crystal Structure and ${ }^{19}$ F NMR Comparison of the Oxime and Oxime Sulfonate Mechanophore}

a)

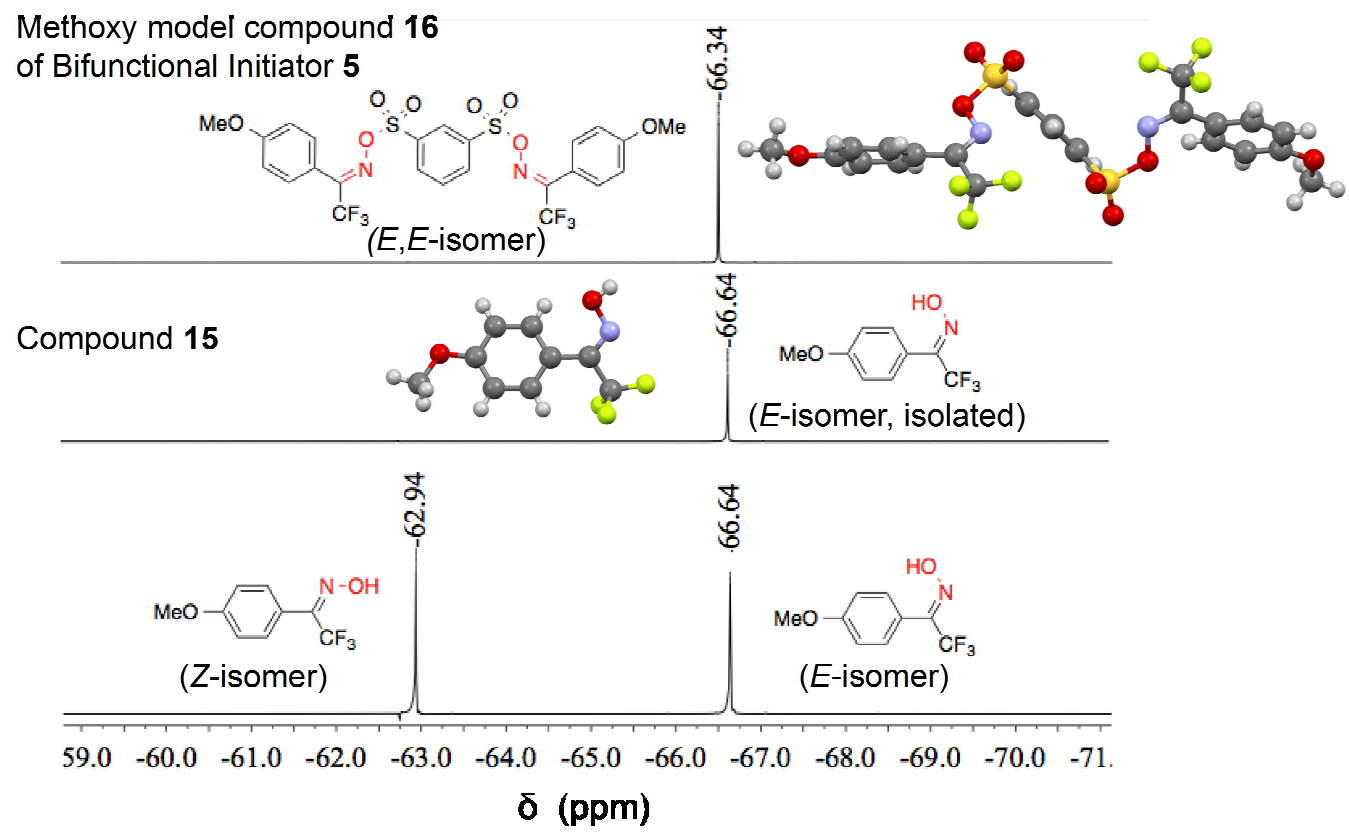

b)

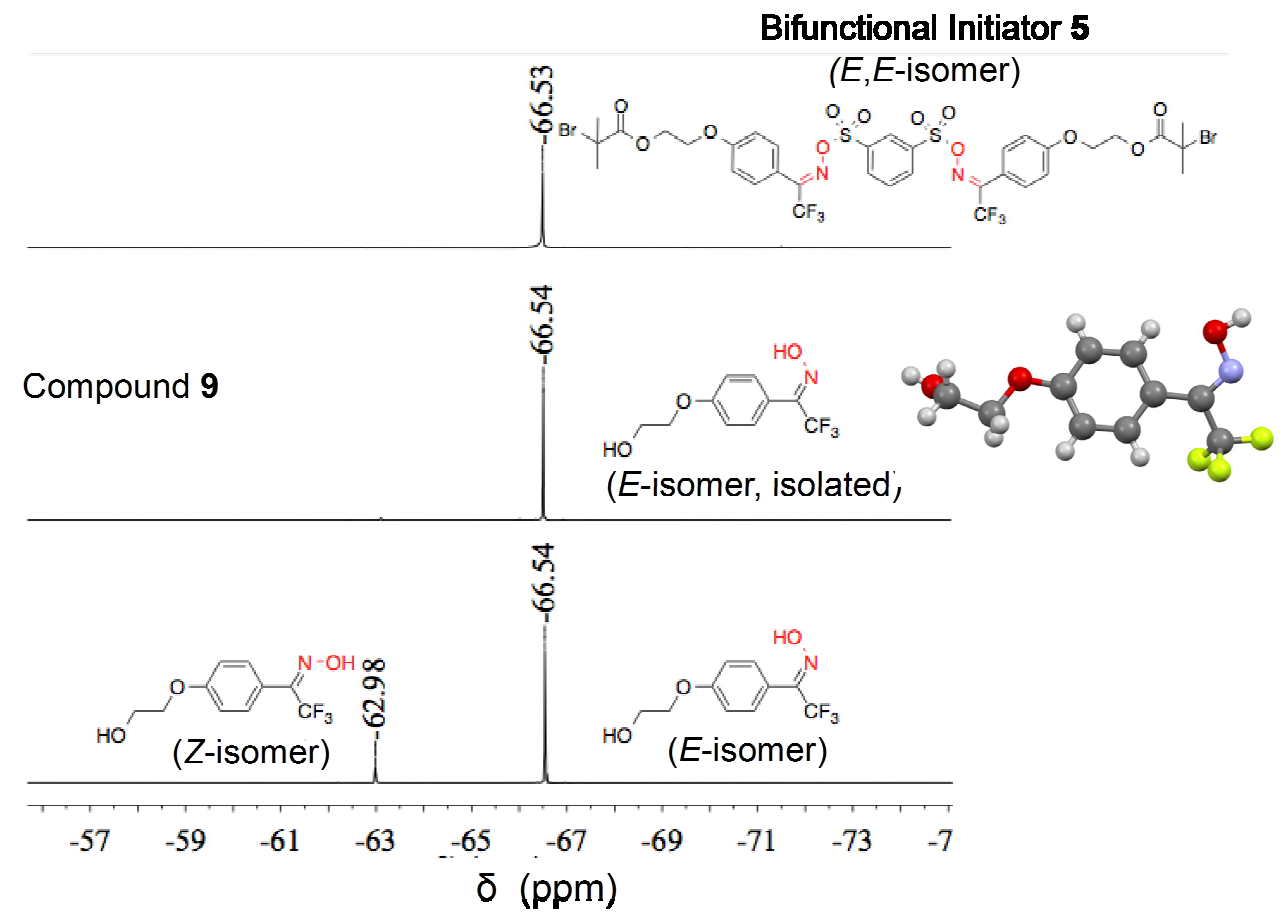

Figure S6. ${ }^{19}$ F NMR spectra and X-ray crystal structure of (a) the methoxy model compound 16 of bifunctional initiator 5, and the corresponding oxime precursor 15; (b) bifunctional initiator $\mathbf{5}$ and the corresponding oxime precursor 9. 


\section{$5.0 \mathrm{pH}$ Measurements}

A pH meter for organic solvents equipped with a $\mathrm{H}^{+}$Ion Selective Electrode (ISE) was used to simultaneously record $\mathrm{pH}$. The electrode was calibrated using buffers $\mathrm{pH} 4$ and 7 . The electrode was dipped in the solution for 30 min before recording the $\mathrm{pH}$. The solution was held in a closed container and stirred continuously throughout the measurements. An average of three measurements is reported. We have carried out the Karl Fisher titration and the water content in the acetonitrile used for sonication experiments is found to be $40 \mathrm{ppm}$. It should be noted that the polymer solution was thoroughly vacuum dried after sonication, and the polymer was re-dissolved in a 99:1 v/v (acetonitrile/water) solution for $\mathrm{pH}$ measurements.

\subsection{Synthesis}
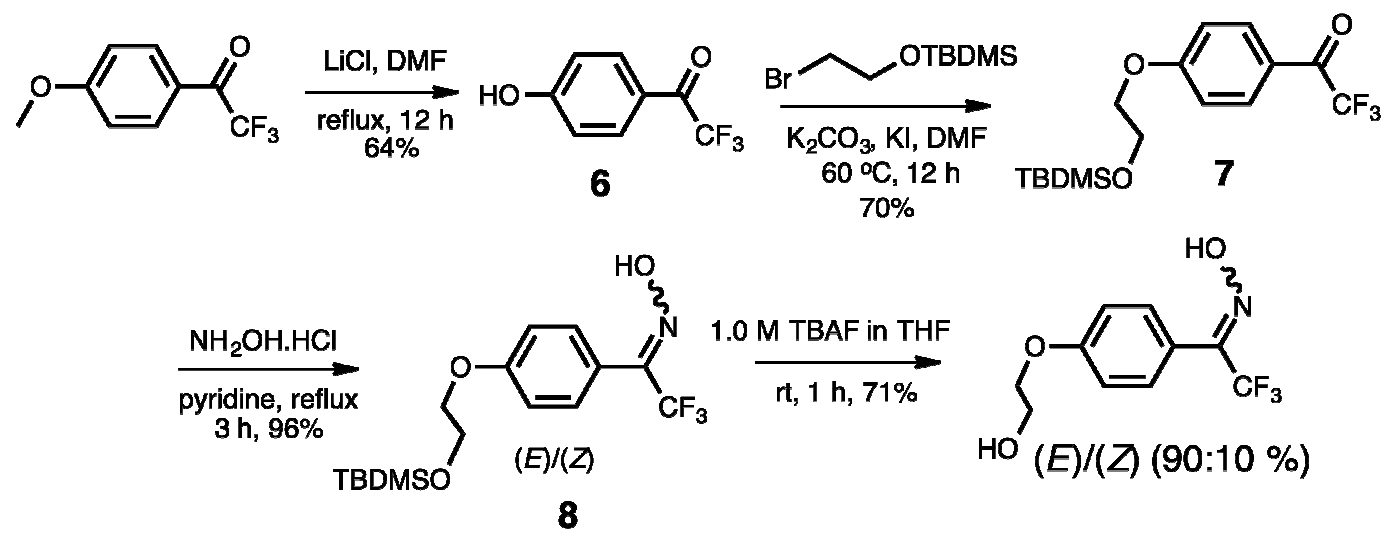<smiles>OCCOc1ccc(/C(=N\O)C(F)(F)F)cc1</smiles>

$(E)$-isomer

9

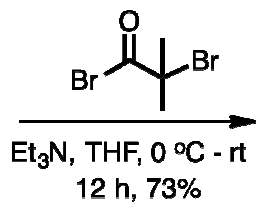

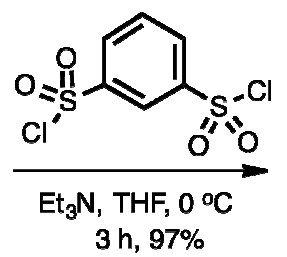

$3 \mathrm{~h}, 97 \%$<smiles>O=S(=O)(O/N=C(/c1ccc(OCCO)cc1)C(F)(F)F)c1cccc(S(=O)(=O)O/N=C(/c2ccc(OCCO)cc2)C(F)(F)F)c1</smiles><smiles>CC(C)(Br)C(=O)OCCOc1ccc(/C(=N/OS(=O)(=O)c2cccc(S(=O)(=O)O/N=C(/c3ccc(OCCOC(=O)C(C)(C)Br)cc3)C(F)(F)F)c2)C(F)(F)F)cc1</smiles>

Scheme S1. Synthesis of the bifunctional initiator 5 with the oxime sulfonate mechanophore. 


\section{2,2,2-trifluoro-1-(4-hydroxyphenyl)ethan-1-one (6)}

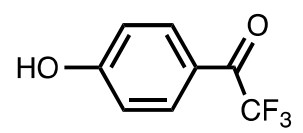

Compound 6 was synthesized following a reported procedure. ${ }^{5}$ 4-Methoxytrifluoroacetophenone (10.00 g, $49 \mathrm{mmol})$ and $\mathrm{LiCl}(6.23 \mathrm{~g}, 147 \mathrm{mmol})$ were taken in $100 \mathrm{~mL}$ DMF and refluxed under nitrogen for $12 \mathrm{~h}$. The reaction mixture was cooled to $\mathrm{rt}$, poured into $500 \mathrm{~mL}$ water, and acidified with $10 \% \mathrm{HCl}$. The product was extracted thrice with diethyl ether. The combined ether layers were washed with brine, dried over $\mathrm{Na}_{2} \mathrm{SO}_{4}$, concentrated using rotary evaporator, and the crude was purified by column chromatography $\left(\mathrm{SiO}_{2}\right)$. The product was eluted with ethyl acetate/hexane $(10 / 90 \mathrm{v} / \mathrm{v})$ to afford the desired product as white solid $(6.0 \mathrm{~g}, 64 \%) .{ }^{1} \mathrm{H}$ NMR $\left(500 \mathrm{MHz}, \mathrm{CDCl}_{3}\right) \delta=5.95(\mathrm{~s}, 1 \mathrm{H}), 6.98(\mathrm{~d}, J=8.75 \mathrm{~Hz}, 2 \mathrm{H}), 8.04(\mathrm{~d}, J=8.14 \mathrm{~Hz}, 2 \mathrm{H}) .{ }^{13} \mathrm{C}$ $\operatorname{NMR}\left(\mathrm{CDCl}_{3}\right) \delta=179.23\left(\mathrm{q}, J_{\mathrm{CF}}=34 \mathrm{~Hz}\right), 162.33,133.36,123.04,117.02\left(\mathrm{q}, J_{\mathrm{CF}}=291 \mathrm{~Hz}\right)$, 116.25. ${ }^{19} \mathrm{~F}$ NMR $\left(\mathrm{CDCl}_{3}\right) \delta=-71.42$. HRMS-ESI $(\mathrm{m} / \mathrm{z})$ : calculated for $\mathrm{C}_{8} \mathrm{H}_{5} \mathrm{O}_{2} \mathrm{~F}_{3}[\mathrm{M}]^{+}$, 190.0242; Found, 190.0242.

\section{1-(4-(2-((tert-butyldimethylsilyl)oxy)ethoxy)phenyl)-2,2,2-trifluoroethan-1-one (7)}

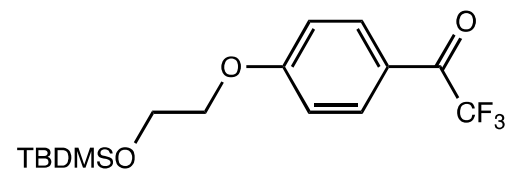

A mixture of 4-Hydroxytrifluoroacetophenone (6) (3.00 g, $20.0 \mathrm{mmol}), \mathrm{K}_{2} \mathrm{CO}_{3}$ (4.15 g, 30.0 mmol), KI (1.66 g, $10.0 \mathrm{mmol})$, and 18-Crown-6 (0.26 g, $1.0 \mathrm{mmol})$ were taken in $60 \mathrm{~mL}$ DMF under nitrogen at room temperature. (2-bromoethoxy)(tert-butyl)dimethylsilane (6.5 mL, 30 mmol) was added and the reaction mixture was heated to $60{ }^{\circ} \mathrm{C}$ and stirred under nitrogen for 12 h. The reaction mixture was cooled to room temperature and poured into $150 \mathrm{~mL}$ water. The product was extracted thrice with ethyl acetate. The combined organic layers were washed with brine, dried over $\mathrm{Na}_{2} \mathrm{SO}_{4}$, concentrated using rotary evaporator, and the crude was purified by column chromatography $\left(\mathrm{SiO}_{2}\right)$. The product was eluted with ethyl acetate/hexane $(5 / 95 \mathrm{v} / \mathrm{v})$ to afford the desired product as a colorless oil $(4.9 \mathrm{~g}, 70 \%)$. ${ }^{1} \mathrm{H}$ NMR $\left(500 \mathrm{MHz}, \mathrm{CDCl}_{3}\right) \delta=8.03$ $8.05(\mathrm{~m}, 2 \mathrm{H}), 7.00-7.02(\mathrm{~m}, 2 \mathrm{H}), 4.15(\mathrm{t}, J=4.9 \mathrm{~Hz}, 2 \mathrm{H}), 4.00(\mathrm{t}, J=4.9 \mathrm{~Hz}, 2 \mathrm{H}), 0.90$ (s, 9H), $0.10(\mathrm{~S}, 6 \mathrm{H}) .{ }^{13} \mathrm{C} \mathrm{NMR}\left(\mathrm{CDCl}_{3}\right) \delta 179.05\left(\mathrm{q}, J_{\mathrm{CF}}=35 \mathrm{~Hz}\right), 165.02,132.87\left(\mathrm{q}, J_{\mathrm{CF}}=2 \mathrm{~Hz}\right)$, $122.90,117.06\left(\mathrm{q}, J_{\mathrm{CF}}=291 \mathrm{~Hz}\right) 115.11,114.17,69.97,61.84,25.99,18.52,-5.10 .{ }^{19} \mathrm{~F} \mathrm{NMR}$ $\left(\mathrm{CDCl}_{3}\right): \delta=-71.34\left(\mathrm{~s}, \mathrm{CF}_{3}\right)$. HRMS-ESI $(\mathrm{m} / \mathrm{z})$ : calculated for $\mathrm{C}_{16} \mathrm{H}_{24} \mathrm{O}_{3} \mathrm{~F}_{3} \mathrm{Si}[\mathrm{M}+\mathrm{H}]^{+}, 349.1447$; Found, 349.1455. 


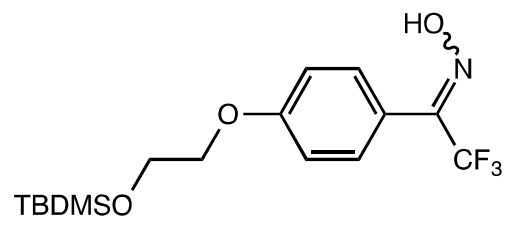

Compound 8 was synthesized following a reported procedure. ${ }^{5}$ Compound 7 (4.4 g, $\left.12.6 \mathrm{mmol}\right)$ and $\mathrm{NH}_{2} \mathrm{OH} . \mathrm{HCl}(2.19 \mathrm{~g}, 31.5 \mathrm{mmol})$ were taken in $30 \mathrm{~mL}$ ethanol under nitrogen at $\mathrm{rt} .70 \mathrm{~mL}$ pyridine was added and the reaction mixture was heated to $60{ }^{\circ} \mathrm{C}$ and stirred under nitrogen for 3 $\mathrm{h}$. TLC analyses indicated the reaction to be complete. The reaction mixture was cooled to rt, and the volatiles were evaporated using rotary evaporator. The product was extracted thrice with ethyl acetate. The combined organic layers were washed with sat. Aqueous $\mathrm{CuSO}_{4}$ solution, brine, dried over $\mathrm{Na}_{2} \mathrm{SO}_{4}$, and concentrated using rotary evaporator. The crude was purified by column chromatography $\left(\mathrm{SiO}_{2}\right)$. The product was eluted with ethyl acetate/hexane $(5 / 95 \mathrm{v} / \mathrm{v})$ to afford the desired product as a white solid (4.4 g, 96\%) as a mixture of E/Z-isomers in 9/1 ratio. ${ }^{1} \mathrm{H}$ NMR (500 MHz, $\left.\mathrm{CDCl}_{3}\right): \delta=9.70(\mathrm{~s}, 0.1 \mathrm{H}), 9.62(\mathrm{~s}, 0.9 \mathrm{H}), 7.56(\mathrm{~d}, 1.8 \mathrm{H}, J=8.7 \mathrm{~Hz}, 2 \mathrm{H})$, $7.41(\mathrm{~d}, J=8.2 \mathrm{~Hz}, 0.2 \mathrm{H}), 7.01-6.98(\mathrm{~m}, 1.8 \mathrm{H}), 6.94-6.92(\mathrm{~m}, 0.2 \mathrm{H}), 4.11(\mathrm{t}, J=5.0 \mathrm{~Hz}, 2 \mathrm{H})$, $4.02(\mathrm{t}, J=5.0 \mathrm{~Hz}, 2 \mathrm{H}), 0.94(\mathrm{~s}, 9 \mathrm{H}), 0.14(\mathrm{~s}, 6 \mathrm{H}) .{ }^{13} \mathrm{C} \mathrm{NMR}\left(\mathrm{CDCl}_{3}\right) \delta 160.61,146.81\left(\mathrm{q}, J_{\mathrm{CF}}=\right.$ $32 \mathrm{~Hz}), 130.66,129.96,120.98\left(\mathrm{q}, J_{\mathrm{CF}}=275 \mathrm{~Hz}\right), 118.24,114.63$ (q, $\left.J_{\mathrm{CF}}=6 \mathrm{~Hz}\right), 69.38,62.15$, 26.04, 18.59, -5.06, -5.12. ${ }^{19} \mathrm{~F}$ NMR $\left(\mathrm{CDCl}_{3}\right) \delta=-62.90 /-66.74\left(\mathrm{~s}, \mathrm{CF}_{3}\right)$. HRMS-ESI $(\mathrm{m} / \mathrm{z})$ : calculated for $\mathrm{C}_{16} \mathrm{H}_{25} \mathrm{NO}_{3} \mathrm{~F}_{3} \mathrm{Si}[\mathrm{M}+\mathrm{H}]^{+}, 364.1556$; Found, 364.1562.

\section{2,2,2-trifluoro-1-(4-(2-hydroxyethoxy)phenyl)ethan-1-one oxime ( $E$-isomer) (9)}

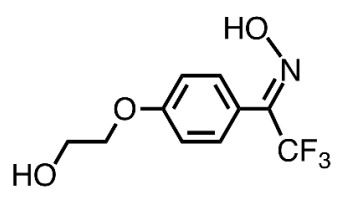

(E-isomer)

Compound 8 (4.0 g, $11.0 \mathrm{mmol})$ was dissolved in $15 \mathrm{~mL}$ THF and $27.5 \mathrm{~mL}$ of $1.0 \mathrm{M}$ TBAF in THF was added. The reaction mixture was stirred at $\mathrm{rt}$ under nitrogen for $1 \mathrm{~h}$, during which the reaction was found to be complete based on TLC analyses. The reaction mixture was poured into $100 \mathrm{~mL}$ sat. $\mathrm{NH}_{4} \mathrm{Cl}$ solution and the product was extracted thrice with ethyl acetate. The combined organic layers were washed thrice with sat. $\mathrm{NH}_{4} \mathrm{Cl}$ solution, water and brine, dried over $\mathrm{Na}_{2} \mathrm{SO}_{4}$, and concentrated using rotary evaporator. The white solid obtained was taken up in excess hexane, filtered, washed with excess hexane, and dried under vacuum to obtain the product as white solid (1.96 g, 71\%) as a mixture of $E / Z$-isomers in 9/1 ratio. Pure $E$-isomer was obtained using column chromatography $\left(\mathrm{SiO}_{2}\right)$. The product was eluted with ethyl acetate/hexane 
$(20 / 80 \mathrm{v} / \mathrm{v})$. The $E$ - conformation of the product was confirmed from crystal structure data. ${ }^{1} \mathrm{H}$ NMR $\left(500 \mathrm{MHz},\left(\mathrm{CD}_{3}\right)_{2} \mathrm{CO}\right) \delta=11.62(\mathrm{~s}, 1 \mathrm{H}), 7.53(\mathrm{~d}, J=8.6 \mathrm{~Hz}, 2 \mathrm{H}), 7.07(\mathrm{~d}, J=8.9 \mathrm{~Hz}, 2 \mathrm{H})$, $\left.4.14(\mathrm{t}, J=4.7 \mathrm{~Hz}, 2 \mathrm{H}), 4.05(\mathrm{t}, J=5.7 \mathrm{~Hz}, 3 \mathrm{H}), 3.90(\mathrm{q}, J=5.1 \mathrm{~Hz}, 2 \mathrm{H}) .{ }^{13} \mathrm{C} \mathrm{NMR}\left(\mathrm{CD}_{3}\right)_{2} \mathrm{CO}\right)$ $\delta=161.33,146.38\left(\mathrm{q}, J_{\mathrm{CF}}=32 \mathrm{~Hz}\right), 131.25,122.32\left(\mathrm{q}, J_{\mathrm{CF}}=274 \mathrm{~Hz}\right), 119.78,115.25,70.70$, 61.23. ${ }^{19} \mathrm{~F}$ NMR $\left.\left(\mathrm{CD}_{3}\right)_{2} \mathrm{CO}\right) \delta=-66.54\left(\mathrm{~s}, \mathrm{CF}_{3}\right)$. HRMS-ESI $(\mathrm{m} / \mathrm{z})$ : calculated for $\mathrm{C}_{10} \mathrm{H}_{11} \mathrm{NO}_{3} \mathrm{~F}_{3}$ $[\mathrm{M}+\mathrm{H}]^{+}, 250.0691$; Found, 250.0702.

\section{Compound (10)}

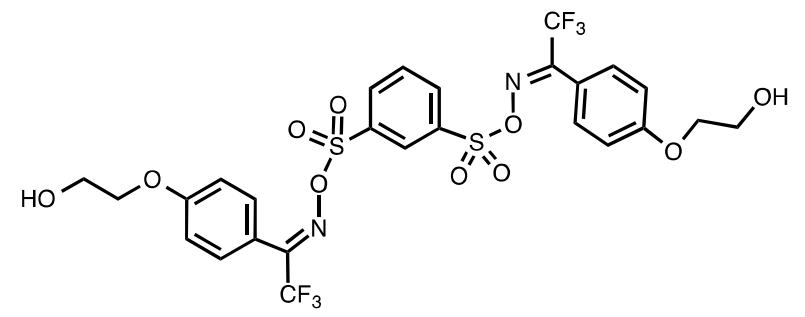

Compound 9 (1.90 g, $7.62 \mathrm{mmol}$ ) (E-isomer) was dissolved in $50 \mathrm{~mL}$ THF and cooled to $0{ }^{\circ} \mathrm{C}$. Benzene-1,3-disulfonyl chloride $(1.10 \mathrm{~g}, 3.8 \mathrm{mmol})$ was added, followed by drop-wise addition of $\mathrm{Et}_{3} \mathrm{~N}(2.2 \mathrm{~mL}, 15.2 \mathrm{mmol})$. The reaction mixture was stirred at $0{ }^{\circ} \mathrm{C}$ for $3 \mathrm{~h}$ and poured into ice water. The product was extracted thrice with ethyl acetate. The combined organic layers were washed with brine, dried over $\mathrm{Na}_{2} \mathrm{SO}_{4}$, and concentrated using rotary evaporator to obtain the product as a white solid $(2.59 \mathrm{~g}, 97 \%)$. The product was taken to the next step without further purification.

\section{Bifunctional Initiator (5)}

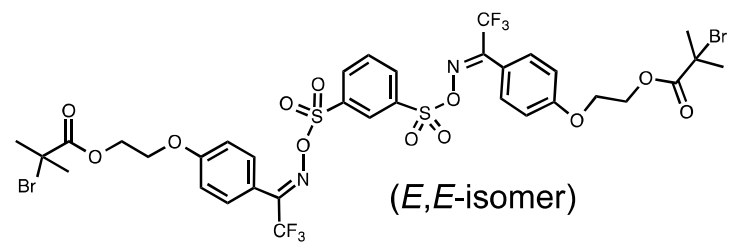

Compound 10 (170 mg, $0.24 \mathrm{mmol})$ was dissolved in $8 \mathrm{~mL}$ THF, followed by the addition of $\mathrm{Et}_{3} \mathrm{~N}(0.1 \mathrm{~mL}, 0.73 \mathrm{mmol})$ and DMAP $(30 \mathrm{mg}, 0.24 \mathrm{mmol})$. The reaction mixture was cooled to $0{ }^{\circ} \mathrm{C}$ and $\alpha$-bromoisobutyryl bromide $(0.1 \mathrm{~mL}, 0.73 \mathrm{mmol})$ was added drop-wise. The reaction mixture was slowly warmed to rt and stirred for $12 \mathrm{~h}$. THF was evaporated and the product was extracted thrice with ethyl acetate. The combined organic layers were washed with brine, dried over $\mathrm{Na}_{2} \mathrm{SO}_{4}$, and concentrated. The product was eluted with ethyl acetate/hexane $(5 / 95 \mathrm{v} / \mathrm{v})$ to afford the desired product as a colorless oil (178 $\mathrm{mg}, 73 \%)$. The $E, E$ conformation of the product was confirmed by comparing the fluorine NMR to the corresponding methoxy analogue (Compound 16). ${ }^{1} \mathrm{H}$ NMR $\left(500 \mathrm{MHz}, \mathrm{CDCl}_{3}\right) \delta=8.48(\mathrm{td}, J=1.8,0.6 \mathrm{~Hz}, 1 \mathrm{H}), 8.40(\mathrm{dd}, J=8.0$, $1.8 \mathrm{~Hz}, 2 \mathrm{H}), 8.03-7.99$ (m, 1H), 7.50-7.49 (m, 4H), 7.12-7.09 (m, 4H), 4.53-4.52(m, 4H), 4.36- 
$4.34(\mathrm{~m}, 4 \mathrm{H}), 1.92(\mathrm{~s}, 12 \mathrm{H}) .{ }^{13} \mathrm{C} \mathrm{NMR}\left(\mathrm{CDCl}_{3}\right) \delta=171.88,161.49,154.73\left(\mathrm{q}, J_{\mathrm{CF}}=33 \mathrm{~Hz}\right)$, $136.33,135.31\left(\mathrm{q}, J_{\mathrm{CF}}=5 \mathrm{~Hz}\right), 131.08,130.61,130.16\left(\mathrm{q}, J_{\mathrm{CF}}=5 \mathrm{~Hz}\right), 119.82\left(\mathrm{q}, J_{\mathrm{CF}}=278 \mathrm{~Hz}\right)$, $116.77,115.29,115.25,66.00,64.06,55.57,31.02,30.95,30.88,30.82 .{ }^{19} \mathrm{~F} \mathrm{NMR}\left(\mathrm{CDCl}_{3}\right) \delta=-$ $66.53\left(\mathrm{~s}, \mathrm{CF}_{3}\right)$. HRMS-ESI $(\mathrm{m} / \mathrm{z})$ : calculated for $\mathrm{C}_{34} \mathrm{H}_{33} \mathrm{~N}_{2} \mathrm{O}_{12} \mathrm{~F}_{6} \mathrm{~S}_{2} \mathrm{Br}_{2}[\mathrm{M}+\mathrm{H}]^{+}$, 996.9746; Found, 996.9736.

${ }^{15} \mathrm{~N}$-labelled Bifunctional Initiator (5*)

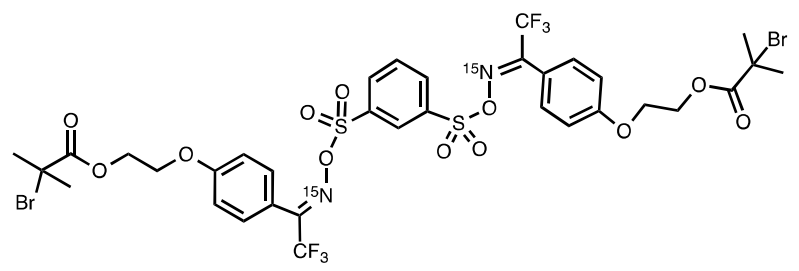

The ${ }^{15} \mathrm{~N}$-labelled bifunctional initiator $\mathbf{5}^{*}$ was synthesized following similar protocols for $\mathbf{5}$ using ${ }^{15} \mathrm{NH}_{2} \mathrm{OH}$.HCl. HRMS-ESI $(m / z)$ : calculated for $\mathrm{C}_{34} \mathrm{H}_{33}{ }^{15} \mathrm{~N}_{2} \mathrm{O}_{12} \mathrm{~F}_{6} \mathrm{~S}_{2} \mathrm{Br}_{2}[\mathrm{M}+\mathrm{H}]+$, 998.9687; Found, 996.9654.

\section{Compound (11)}

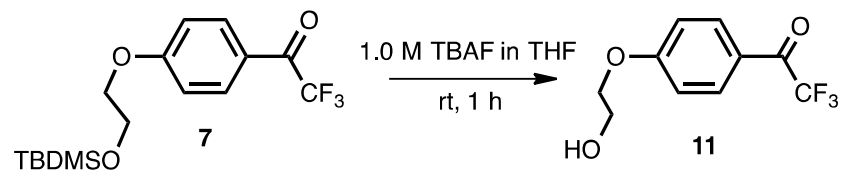

Compound 7 (4.0 g, $11.5 \mathrm{mmol})$ was dissolved in $30 \mathrm{~mL}$ THF and $19 \mathrm{~mL}$ of $1.0 \mathrm{M}$ TBAF in THF was added. The reaction mixture was stirred at $\mathrm{rt}$ under nitrogen for $1 \mathrm{~h}$, during which the reaction was found to be complete based on TLC analyses. The reaction mixture was poured into $100 \mathrm{~mL}$ sat. $\mathrm{NH}_{4} \mathrm{Cl}$ solution and the product was extracted thrice with ethyl acetate. The combined organic layers were washed thrice with sat. $\mathrm{NH}_{4} \mathrm{Cl}$ solution, water and brine, dried over $\mathrm{Na}_{2} \mathrm{SO}_{4}$, and concentrated using rotary evaporator. The yellow solid obtained was taken up in excess hexane, filtered, washed with excess hexane, and dried under vacuum to obtain the product as yellow solid. The product was taken to the next step without further purification.

\section{Compound (12) (PMA-Ketone initiator)}

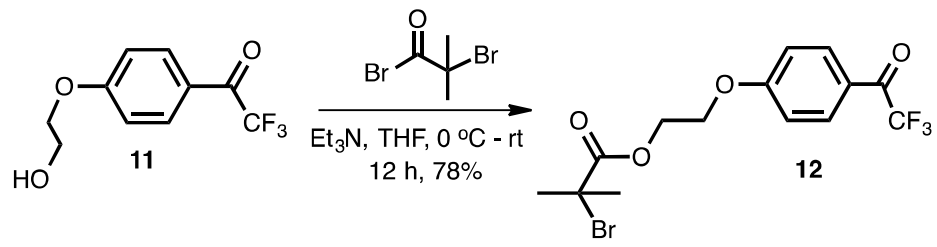


Compound 11 ( $2.0 \mathrm{~g}, 8.54 \mathrm{mmol})$ was dissolved in $100 \mathrm{~mL}$ THF, followed by the addition of $\mathrm{Et}_{3} \mathrm{~N}(3.6 \mathrm{~mL}, 25.60 \mathrm{mmol})$ and DMAP $(1.0 \mathrm{~g}, 8.54 \mathrm{mmol})$. The reaction mixture was cooled to $0{ }^{\circ} \mathrm{C}$ and $\alpha$-bromoisobutyryl bromide $(1.6 \mathrm{~mL}, 12.80 \mathrm{mmol})$ was added drop wise. The reaction mixture was slowly warmed to rt and stirred for $12 \mathrm{~h}$. THF was evaporated and the product was extracted thrice with ethyl acetate. The combined organic layers were washed with brine, dried over $\mathrm{Na}_{2} \mathrm{SO}_{4}$, and concentrated. The product was eluted with hexane to afford the desired product as pale yellow oil $\left(3.1 \mathrm{~g}, 78 \%\right.$ combined yield). ${ }^{1} \mathrm{H}$ NMR $\left(500 \mathrm{MHz}, \mathrm{CDCl}_{3}\right) \delta=8.06-$ $8.02(\mathrm{~m}, 2 \mathrm{H}), 7.03-7.00(\mathrm{~m}, 2 \mathrm{H}), 4.56(\mathrm{dd}, J=5.3,4.2 \mathrm{~Hz}, 2 \mathrm{H}), 4.33(\mathrm{dd}, J=5.3,4.2 \mathrm{~Hz}, 2 \mathrm{H})$, $1.92(\mathrm{~s}, 6 \mathrm{H}) .{ }^{13} \mathrm{C}$ NMR $\left(\mathrm{CDCl}_{3}\right) \delta=178.99\left(\mathrm{q}, J_{\mathrm{CF}}=35 \mathrm{~Hz}\right), 171.67,164.29,132.87,123.35$, $116.97\left(\mathrm{q}, J_{\mathrm{CF}}=291 \mathrm{~Hz}\right), 115.10,66.04,63.71,55.41,30.77,30.71 .{ }^{19} \mathrm{~F}$ NMR $\left(\mathrm{CDCl}_{3}\right) \delta=-$ $71.53\left(\mathrm{~s}, \mathrm{CF}_{3}\right)$. HRMS-ESI $(\mathrm{m} / \mathrm{z})$ : calculated for $\mathrm{C}_{14} \mathrm{H}_{15} \mathrm{O}_{4} \mathrm{~F}_{3} \mathrm{Br}[\mathrm{M}+\mathrm{H}]^{+}, 383.0106$; Found, 383.0099 .

\section{Compound (13) (PMA-NOH initiator)}

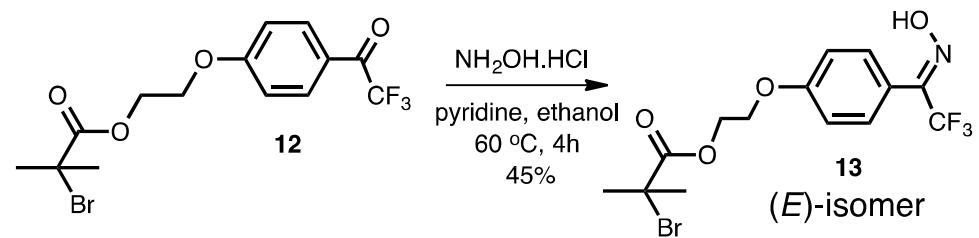

Compound 12 (400 mg, $1.00 \mathrm{mmol}$ ) and $\mathrm{NH}_{2} \mathrm{OH} . \mathrm{HCl}(218 \mathrm{mg}, 3.13 \mathrm{mmol}$ ) were taken in $10 \mathrm{~mL}$ ethanol under nitrogen at rt. $15 \mathrm{~mL}$ pyridine was added and the reaction mixture was heated to 60 ${ }^{\circ} \mathrm{C}$ and stirred under nitrogen for $4 \mathrm{~h}$. The reaction mixture was cooled to rt, and the volatiles were evaporated using rotary evaporator. The product was extracted thrice with ethyl acetate. The combined organic layers were washed with sat. aq. $\mathrm{CuSO}_{4}$ solution, brine, dried over $\mathrm{Na}_{2} \mathrm{SO}_{4}$, and concentrated using rotary evaporator. The crude (mixture of $E / Z$ isomers) was purified by column chromatography $\left(\mathrm{SiO}_{2}\right)$. The product was eluted with ethyl acetate/hexane $(10 / 90 \mathrm{v} / \mathrm{v})$ to afford the $E$-isomer $(188 \mathrm{mg}, 45 \%) .{ }^{1} \mathrm{H} \mathrm{NMR}\left(500 \mathrm{MHz}, \mathrm{CDCl}_{3}\right) \delta=8.46(\mathrm{~s}, 1 \mathrm{H})$, $7.53(\mathrm{~d}, J=8.8 \mathrm{~Hz}, 2 \mathrm{H}), 7.00(\mathrm{~d}, J=8.8 \mathrm{~Hz}, 2 \mathrm{H}), 4.55(\mathrm{t}, J=4.6 \mathrm{~Hz}, 2 \mathrm{H}), 4.27$ (t, $J=4.5 \mathrm{~Hz}$, $2 \mathrm{H}), 1.93(\mathrm{~s}, 6 \mathrm{H}) .{ }^{13} \mathrm{C} \mathrm{NMR}\left(\mathrm{CDCl}_{3}\right) \delta=171.89,160.11,147.04,130.70,130.11,118.70,114.82$, 114.76, 65.74, 64.15, 55.52, 30.80. ${ }^{19} \mathrm{~F}$ NMR $\left(\mathrm{CDCl}_{3}\right) \delta=-66.58\left(\mathrm{~s}, \mathrm{CF}_{3}\right)$. HRMS-ESI $(\mathrm{m} / \mathrm{z})$ : calculated for $\mathrm{C}_{14} \mathrm{H}_{16} \mathrm{NO}_{4} \mathrm{~F}_{3} \mathrm{Br}[\mathrm{M}+\mathrm{H}]^{+}$, 398.0215; Found, 398.0211 .

\section{${ }^{15} \mathrm{~N}$-labelled Compound 13* (PMA- ${ }^{15} \mathrm{NOH}$ initiator)}

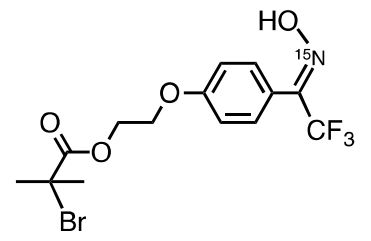


The ${ }^{15} \mathrm{~N}$-labelled $\mathbf{1 3} *$ was synthesized following similar procedure for $\mathbf{1 3}$ using ${ }^{15} \mathrm{NH}_{2} \mathrm{OH} . \mathrm{HCl}$.

\section{Compound (14) (PMA-SO ${ }_{3} \mathrm{R}$ initiator)}

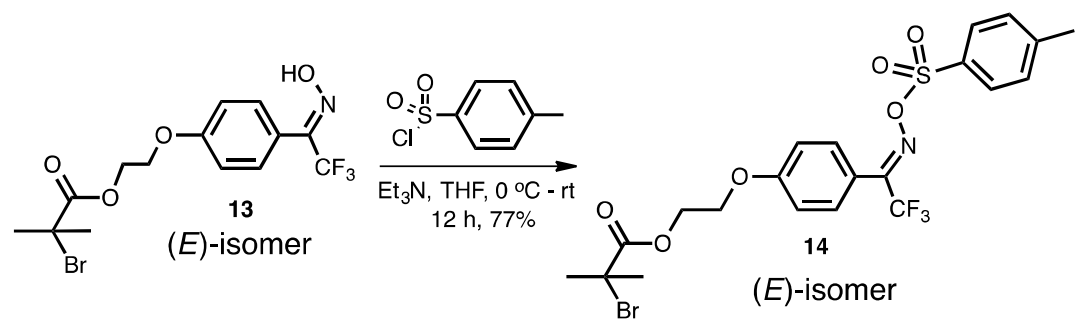

Compound 13 (70 mg, $0.18 \mathrm{mmol}$ ) was dissolved in $7.0 \mathrm{~mL}$ THF and cooled to $0{ }^{\circ} \mathrm{C}$. p-toluene sulfonyl chloride (50 mg, $0.26 \mathrm{mmol}$ ) was added, followed by addition of $\mathrm{Et}_{3} \mathrm{~N}(0.05 \mathrm{~mL}, 0.35$ $\mathrm{mmol}$ ). The reaction mixture was slowly warmed to rt and stirred for $12 \mathrm{~h}$. THF was evaporated and the product was extracted thrice with ethyl ether. The combined organic layers were washed with brine, dried over $\mathrm{Na}_{2} \mathrm{SO}_{4}$, and concentrated using rotary evaporator. The crude was purified by column chromatography $\left(\mathrm{SiO}_{2}\right)$. The product was eluted with ethyl acetate/hexane $(15 / 85 \mathrm{v} / \mathrm{v})$ to afford the desired $E$-isomer product as pale yellow oil (75 mg, 77\%). ${ }^{1} \mathrm{H}$ NMR (500 MHz, $\left.\mathrm{CDCl}_{3}\right) \delta=7.89(\mathrm{~d}, J=8.2 \mathrm{~Hz}, 2 \mathrm{H}), 7.44(\mathrm{~d}, J=7.8 \mathrm{~Hz}, 2 \mathrm{H}), 7.38(\mathrm{~d}, J=8.2 \mathrm{~Hz}, 2 \mathrm{H}), 6.99(\mathrm{~d}, J$ $=9.0 \mathrm{~Hz}, 2 \mathrm{H}), 4.54(\mathrm{t}, J=3.7 \mathrm{~Hz}, 2 \mathrm{H}), 4.27(\mathrm{t}, J=3.7 \mathrm{~Hz}, 2 \mathrm{H}), 2.47(\mathrm{~s}, 3 \mathrm{H}), 1.93(\mathrm{~s}, 6 \mathrm{H}) .{ }^{13} \mathrm{C}$ $\operatorname{NMR}\left(\mathrm{CDCl}_{3}\right) \delta=171.77,161.02,153.28\left(\mathrm{q}, J_{\mathrm{CF}}=33 \mathrm{~Hz}\right), 146.22,131.33,130.88,129.99$, $129.42,129.25,122.39,119.90\left(\mathrm{q}, J_{\mathrm{CF}}=179 \mathrm{~Hz}\right), 117.21,115.00,65.82,64.00,55.49,30.81$, 21.95. ${ }^{19} \mathrm{~F}$ NMR $\left(\mathrm{CDCl}_{3}\right) \delta=-66.62\left(\mathrm{~s}, \mathrm{CF}_{3}\right)$. HRMS-ESI $(\mathrm{m} / \mathrm{z})$ : calculated for $\mathrm{C}_{21} \mathrm{H}_{22} \mathrm{NO}_{6} \mathrm{SBrF}_{3}$ $[\mathrm{M}+\mathrm{H}]^{+}, 552.0303$; Found, 552.0287.

\section{(E)-2,2,2-trifluoro-1-(4-methoxyphenyl)ethan-1-one oxime (15)}

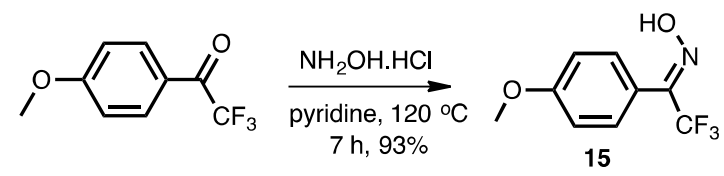

$(E)$-isomer

Compound 14 was synthesized following a reported procedure. ${ }^{6}$ 2,2,2-trifluoroethan-1(4methoxyphenyl) ethan-1-one (1.0 g, $4.9 \mathrm{mmol})$ and $\mathrm{NH}_{2} \mathrm{OH} . \mathrm{HCl}(0.51 \mathrm{~g}, 7.4 \mathrm{mmol})$ were taken in a flask under nitrogen at rt. $10 \mathrm{~mL}$ pyridine was added and the reaction mixture was heated to $120{ }^{\circ} \mathrm{C}$ for $7 \mathrm{~h}$. TLC analyses indicated the reaction to be complete. The reaction mixture was cooled to $\mathrm{rt}$, and the volatiles were evaporated using rotary evaporator. The crude was taken up in methyl tert-butyl ether and washed with $50 \mathrm{~mL}(0.2 \mathrm{M})$ citric acid and water. The combined organic layers were dried over $\mathrm{Na}_{2} \mathrm{SO}_{4}$, and concentrated using rotary evaporator. The crude was purified by column chromatography $\left(\mathrm{SiO}_{2}\right)$. The product was eluted with ethyl acetate/hexane $(5 / 95 \mathrm{v} / \mathrm{v})$ to afford the $E$-isomer of the product as off-white solid $(1.0 \mathrm{~g}, 93 \%)$. The $E$ - 
conformation of the product was confirmed from crystal structure data. ${ }^{1} \mathrm{H}$ NMR $(500 \mathrm{MHz}$, $\left.\mathrm{CDCl}_{3}\right): \delta=9.06(\mathrm{~s}, 1 \mathrm{H}), 7.57(\mathrm{~d}, J=8.8 \mathrm{~Hz}, 2 \mathrm{H}), 7.00(\mathrm{~d}, J=8.4 \mathrm{~Hz}, 2 \mathrm{H}), 3.86(\mathrm{~s}, 3 \mathrm{H}) .{ }^{13} \mathrm{C}$ $\operatorname{NMR}\left(\mathrm{CDCl}_{3}\right) \delta 161.29,147.05\left(\mathrm{q}, J_{\mathrm{CF}}=32 \mathrm{~Hz}\right), 130.66,124.17,121.98,119.79,118.04,114.11$, 55.49. ${ }^{19} \mathrm{~F} \mathrm{NMR}\left(\mathrm{CDCl}_{3}\right) \delta=-66.76\left(\mathrm{~s}, \mathrm{CF}_{3}\right)$. HRMS-ESI $(\mathrm{m} / \mathrm{z})$ : calculated for $\mathrm{C}_{9} \mathrm{H}_{9} \mathrm{NO}_{2} \mathrm{~F}_{3}$ $[\mathrm{M}+\mathrm{H}]^{+}, 220.0585 ;$ Found, 220.0585.

\section{Compound 16}

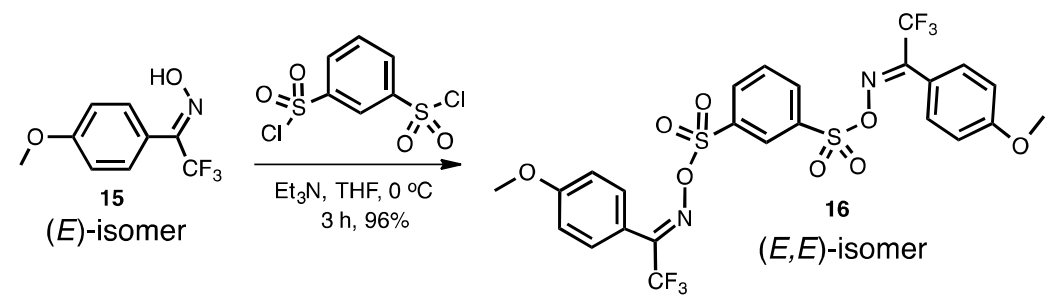

Compound 15 ( $0.50 \mathrm{~g}, 2.28 \mathrm{mmol})$ was dissolved in $10 \mathrm{~mL}$ THF and cooled to $0{ }^{\circ} \mathrm{C}$. Benzene1,3-disulfonyl chloride $(0.38 \mathrm{~g}, 1.37 \mathrm{mmol})$ was added, followed by drop-wise addition of $\mathrm{Et}_{3} \mathrm{~N}$ $(0.50 \mathrm{~mL}, 3.42 \mathrm{mmol})$. The reaction mixture was stirred at $0{ }^{\circ} \mathrm{C}$ for $3 \mathrm{~h}$ and poured into ice water. The product was extracted thrice with ethyl acetate. The combined organic layers were washed with brine, dried over $\mathrm{Na}_{2} \mathrm{SO}_{4}$, and concentrated using rotary evaporator. The crude was purified by column chromatography $\left(\mathrm{SiO}_{2}\right)$. The product was eluted with ethyl acetate/hexane $(20 / 80 \mathrm{v} / \mathrm{v})$ to afford the $E, E$-isomer of the product as white solid $(0.70 \mathrm{~g}, 96 \%)$. The $(E, E)$ - conformation of the product was confirmed from crystal structure data. ${ }^{1} \mathrm{H}$ NMR $\left(500 \mathrm{MHz}, \mathrm{CDCl}_{3}\right): \delta=8.62(\mathrm{~s}$, $1 \mathrm{H}), 8.36-8.34$ (dd, $J=8.0 \mathrm{~Hz}, 1.8 \mathrm{~Hz}, 2 \mathrm{H}), 7.87$ (t, $J=8.0 \mathrm{~Hz}, 1 \mathrm{H}), 7.47$ (d, $J=8.9 \mathrm{~Hz}, 4 \mathrm{H})$, $6.99(\mathrm{~d}, J=9.0 \mathrm{~Hz}, 4 \mathrm{H}), 3.87(\mathrm{~s}, 6 \mathrm{H}) .{ }^{13} \mathrm{C} \mathrm{NMR}\left(\mathrm{CDCl}_{3}\right) \delta=162.54,154.61\left(\mathrm{q}, J_{\mathrm{CF}}=33 \mathrm{~Hz}\right)$, $136.20,135.17,130.95,130.50,130.01,128.84$ (q, $\left.J_{\mathrm{CF}}=163 \mathrm{~Hz}\right), 119.76\left(\mathrm{q}, J_{\mathrm{CF}}=278 \mathrm{~Hz}\right)$, 116.02, 114.50, 55.61, 46.57, 8.79. ${ }^{19} \mathrm{~F} \mathrm{NMR}\left(\mathrm{CDCl}_{3}\right) \delta=-66.42\left(\mathrm{~s}, \mathrm{CF}_{3}\right)$. HRMS-ESI $(\mathrm{m} / \mathrm{z})$ : calculated for $\mathrm{C}_{24} \mathrm{H}_{18} \mathrm{~N} 2 \mathrm{O}_{8} \mathrm{~F}_{6} \mathrm{~S}_{2} \mathrm{Na}[\mathrm{M}+\mathrm{Na}]^{+}$, 663.0316; Found, 663.0306.

\subsection{Polymer Synthesis}

Polymer 1 was synthesized through a single electron transfer living radical polymerization (SETLRP) ${ }^{13}$ using the bifunctional initiator 5. Methyl acrylate (MA) was filtered through basic alumina to remove inhibitor. $\mathrm{Cu}(0)$ powder $(1.30 \mathrm{mg}, 0.020 \mathrm{mmol})$ was added under nitrogen to an oven dried $10 \mathrm{~mL}$ Schlenk flask equipped with a stir bar. $1.0 \mathrm{~mL}$ anhydrous acetonitrile was added to the schlenk flask and sonicated for $20 \mathrm{~min}$. A mixture of $\mathrm{Me}_{6} \mathrm{TREN}$ (5.34 $\mu \mathrm{L}, 0.020$ $\mathrm{mmol})$, bifunctional initiator $5(5.00 \mathrm{mg}, 0.005 \mathrm{mmol})$ and MA $(3.00 \mathrm{~mL}, 33.1 \mathrm{mmol})$ was added under nitrogen and the schlenk flask was immediately immersed in liquid nitrogen. The flask was subjected to three freeze-pump-thaw cycles and backfilled with $\mathrm{N}_{2}$. The reaction mixture was allowed to stir at room temperature for $2.0 \mathrm{~h}$. The polymerization was quenched by immersing the flask in liquid nitrogen. The crude was diluted with $20 \mathrm{~mL}$ THF and passed through a silica 
pad to remove copper. The reaction mixture was concentrated to about $4 \mathrm{~mL}$ using rotary evaporator. A large excess of methanol was taken in a $500 \mathrm{~mL}$ flask equipped with a teflon stirrer. The reaction mixture was added drop-wise into stirring methanol. The white precipitate obtained was re-dissolved in a small amount of THF and re-precipitated into large excess of stirring methanol. The white precipitate obtained was dried under vacuum to yield polymer $\mathbf{1}$ as a white solid (1.0 g, 35\%). GPC (THF, polystyrene standards) $M_{\mathrm{n}}=189,400 \mathrm{kDa}, M_{\mathrm{w}} / M_{\mathrm{n}}=1.12$. Polymer $1_{\text {low Mw }}\left(M_{\mathrm{n}}=38.2 \mathrm{kDa}\right.$; PDI $\left.=1.13\right)$, polymers $2-4$ shown in Chart 1 , ${ }^{15} \mathrm{~N}$-labelled polymers 1* and 4*, and PMA polymer were also synthesized through SET-LRP following the same procedure using the corresponding $\alpha$-bromoisobutyryl initiators. Ethyl $\alpha$-bromoisobutyrate initiator was used to obtain the PMA polymer.

\subsection{X-ray Crystallographic Data}

\subsection{Crystal Structure of Compound 9}

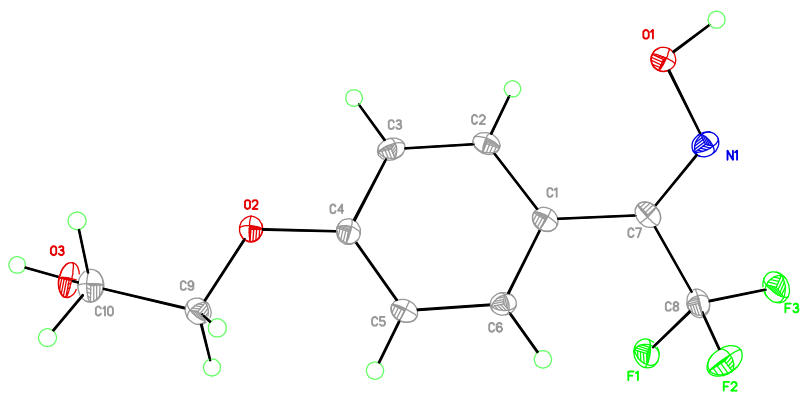

\section{Crystal data and structure refinement for Compound 9:}

Empirical formula

Formula weight

Temperature

Wavelength

Crystal system

Space group

Unit cell dimensions

Volume

Z

Density (calculated)

Absorption coefficient

$\mathrm{F}(000)$
C10 H10 F3 N O3

249.19

$100(2) \mathrm{K}$

$1.54178 \AA$

Monoclinic

$\mathrm{P} 2{ }_{1} / \mathrm{n}$

$\mathrm{a}=5.0912(3) \AA \quad \mathrm{a}=90^{\circ}$.

$\mathrm{b}=8.9533(5) \AA \quad \mathrm{b}=94.2965(18)^{\circ}$.

$\mathrm{c}=23.0489(12) \AA \quad \mathrm{g}=90^{\circ}$.

1047.69(10) $\AA^{3}$

4

$1.580 \mathrm{Mg} / \mathrm{m}^{3}$

$1.330 \mathrm{~mm}^{-1}$

512 
Crystal size

Theta range for data collection

Index ranges

Reflections collected

Independent reflections

Completeness to theta $=67.679^{\circ}$

Absorption correction

Max. and min. transmission

Refinement method

Data / restraints / parameters

Goodness-of-fit on $\mathrm{F}^{2}$

Final R indices [I $>2 \operatorname{sigma}(\mathrm{I})]$

$\mathrm{R}$ indices (all data)

Extinction coefficient

Largest diff. peak and hole 0.678 and -0.399 e. $\AA^{-3}$

\subsection{Crystal Structure of Compound 15}

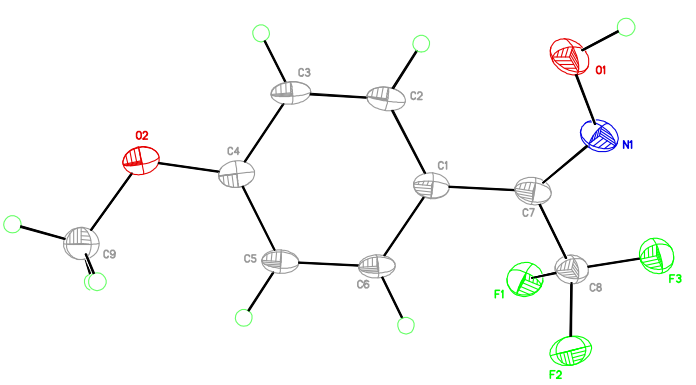

$0.502 \times 0.455 \times 0.012 \mathrm{~mm}^{3}$

3.846 to $68.346^{\circ}$.

$-6<=\mathrm{h}<=6,-10<=\mathrm{k}<=10,-27<=\mathrm{l}<=26$

12994

$1921[\mathrm{R}($ int $)=0.0342]$

$99.9 \%$

Integration

0.98669 and 0.71896

Full-matrix least-squares on $\mathrm{F}^{2}$

$1921 / 0 / 161$

1.179

$\mathrm{R} 1=0.0547, \mathrm{wR} 2=0.1225$

$\mathrm{R} 1=0.0576, \mathrm{wR} 2=0.1237$

$0.0090(7)$

\section{Crystal data and structure refinement for Compound 15:}

Empirical formula

Formula weight

Temperature

Wavelength

Crystal system

Space group

Unit cell dimensions

Volume

Z

\section{C9 H8 F3 N O2}

219.16

100(2) K

$1.54178 \AA$

Orthorhombic

Pben

$\mathrm{a}=24.3659(11) \AA$ $\mathrm{a}=90^{\circ}$.

$\mathrm{b}=10.1608(5) \AA$

$b=90^{\circ}$.

$\mathrm{c}=7.6406(3) \AA$

$\mathrm{g}=90^{\circ}$. 


\begin{tabular}{ll} 
Density (calculated) & $1.539 \mathrm{Mg} / \mathrm{m}^{3}$ \\
Absorption coefficient & $1.307 \mathrm{~mm}^{-1}$ \\
$\mathrm{~F}(000)$ & 896 \\
Crystal size & $0.504 \times 0.333 \times 0.332 \mathrm{~mm}^{3}$ \\
Theta range for data collection & 3.628 to $72.182^{\circ}$. \\
Index ranges & $-30<=\mathrm{h}<=30,-12<=\mathrm{k}<=12,-9<=1<=9$ \\
Reflections collected & 39997 \\
Independent reflections & $1874[\mathrm{R}(\mathrm{int})=0.0304]$ \\
Completeness to theta $=67.679^{\circ}$ & $99.9 \%$ \\
Absorption correction & Integration \\
Max. and min. transmission & 0.79188 and 0.60764 \\
Refinement method & Full-matrix least-squares on $\mathrm{F}^{2}$ \\
Data / restraints / parameters & $1874 / 0 / 141$ \\
Goodness-of-fit on F & \\
Final R indices [I $>2$ sigma(I) & 1.184 \\
R indices (all data) & $\mathrm{R} 1=0.0476, \mathrm{wR} 2=0.1069$ \\
Extinction coefficient & 0.481 and $-0.699 \mathrm{e} . \AA^{-3}$ \\
Largest diff. peak and hole & \\
& $0.0444(18)$ \\
\hline
\end{tabular}

\subsection{Crystal Structure of the Methoxy Model Compound 16 of Bifunctional Initiator 5}

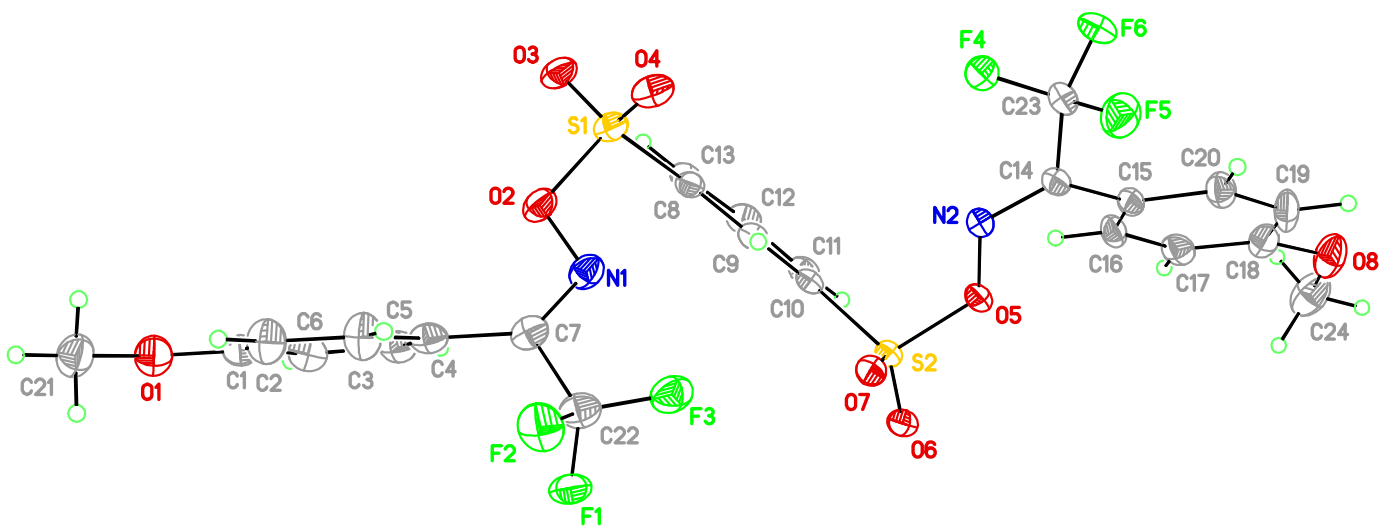

\section{Crystal data and structure refinement for Compound 16:}

Empirical formula

Formula weight

Temperature
C24 H18 F6 N2 O8 S2

640.52

$100(2) \mathrm{K}$ 
Wavelength

Crystal system

Space group

Unit cell dimensions

Volume

Z

Density (calculated)

Absorption coefficient

$\mathrm{F}(000)$

Crystal size

Theta range for data collection

Index ranges

Reflections collected

Independent reflections

Completeness to theta $=67.679^{\circ}$

Absorption correction

Max. and min. transmission

Refinement method

Data / restraints / parameters

Goodness-of-fit on $\mathrm{F}^{2}$

Final $\mathrm{R}$ indices [I $>2 \operatorname{sigma}(\mathrm{I})]$

$\mathrm{R}$ indices (all data)

Extinction coefficient

Largest diff. peak and hole
$1.54178 \AA$

Triclinic

P-1

$\mathrm{a}=9.1636(4) \AA$

$a=95.096(2)^{\circ}$.

$\mathrm{b}=11.8078(5) \AA$

$\mathrm{b}=100.040(2)^{\circ}$.

$\mathrm{c}=25.3656(10) \AA$

$\mathrm{g}=90.100(2)^{\circ}$.

4

$1.581 \mathrm{Mg} / \mathrm{m}^{3}$

$2.657 \mathrm{~mm}^{-1}$

1304

$0.312 \times 0.297 \times 0.028 \mathrm{~mm}^{3}$

3.554 to $68.578^{\circ}$.

$-9<=\mathrm{h}<=11,-14<=\mathrm{k}<=14,-30<=\mathrm{l}<=30$

56078

$9835[\mathrm{R}(\mathrm{int})=0.0834]$

$99.8 \%$

Integration

0.95575 and 0.58243

Full-matrix least-squares on $\mathrm{F}^{2}$

9835 / 472 / 909

1.060

$\mathrm{R} 1=0.0713, \mathrm{wR} 2=0.1721$

$\mathrm{R} 1=0.0903, \mathrm{wR} 2=0.1836$

$\mathrm{n} / \mathrm{a}$

0.818 and -0.665 e. $\AA^{-3}$ 


\section{$9.0{ }^{1} \mathrm{H},{ }^{13} \mathrm{C}$, and ${ }^{19} \mathrm{~F}$ NMR Spectra}
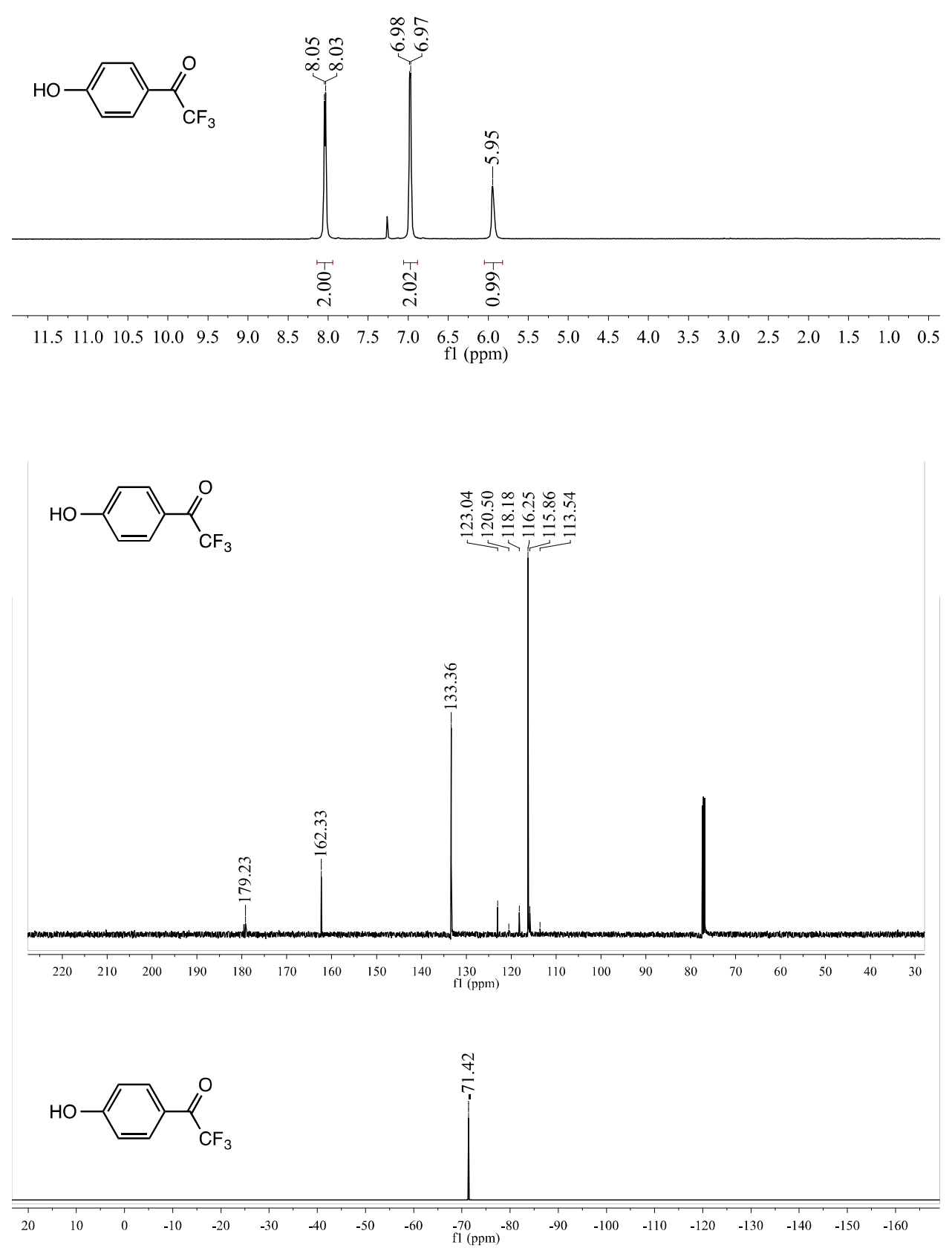

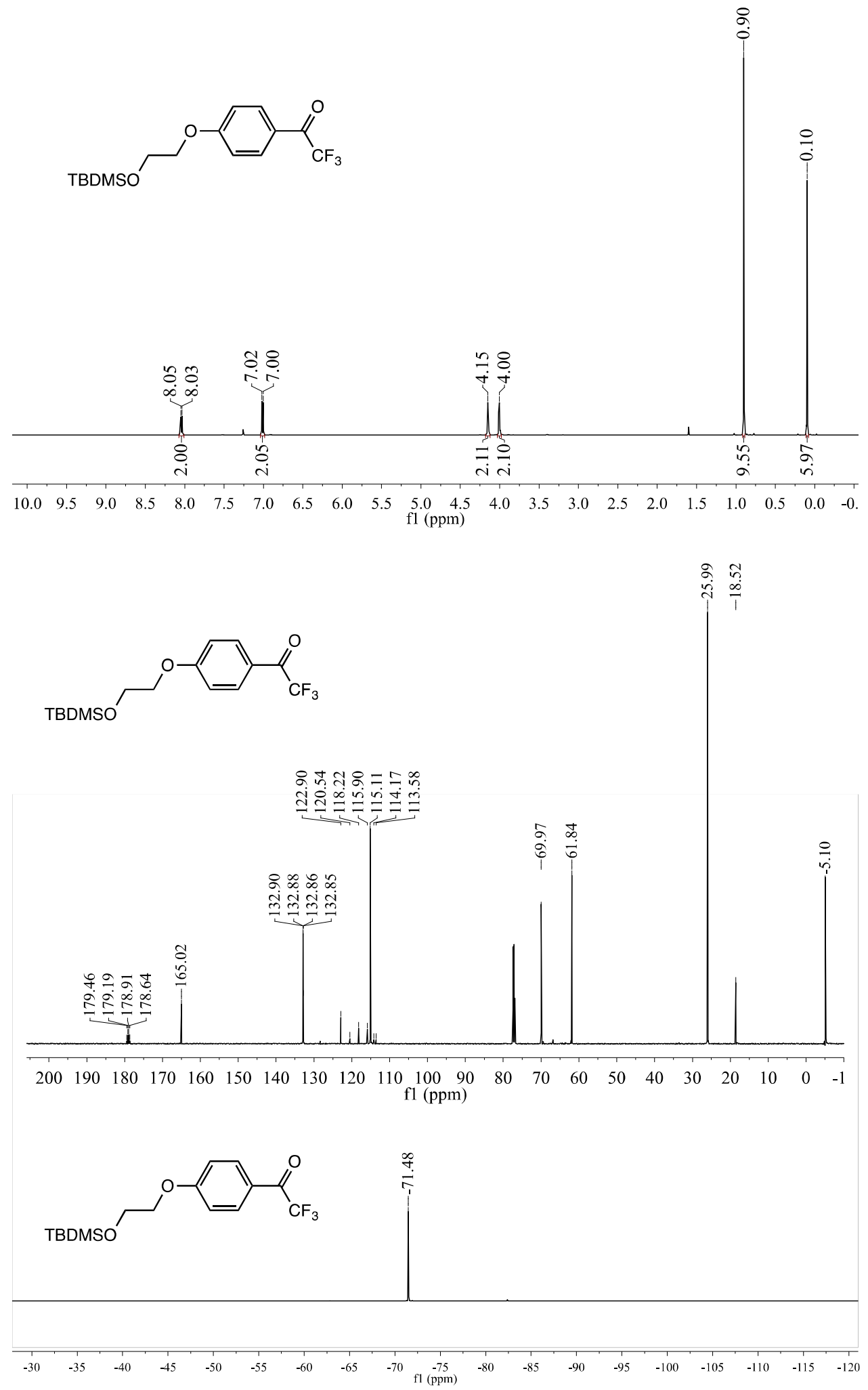

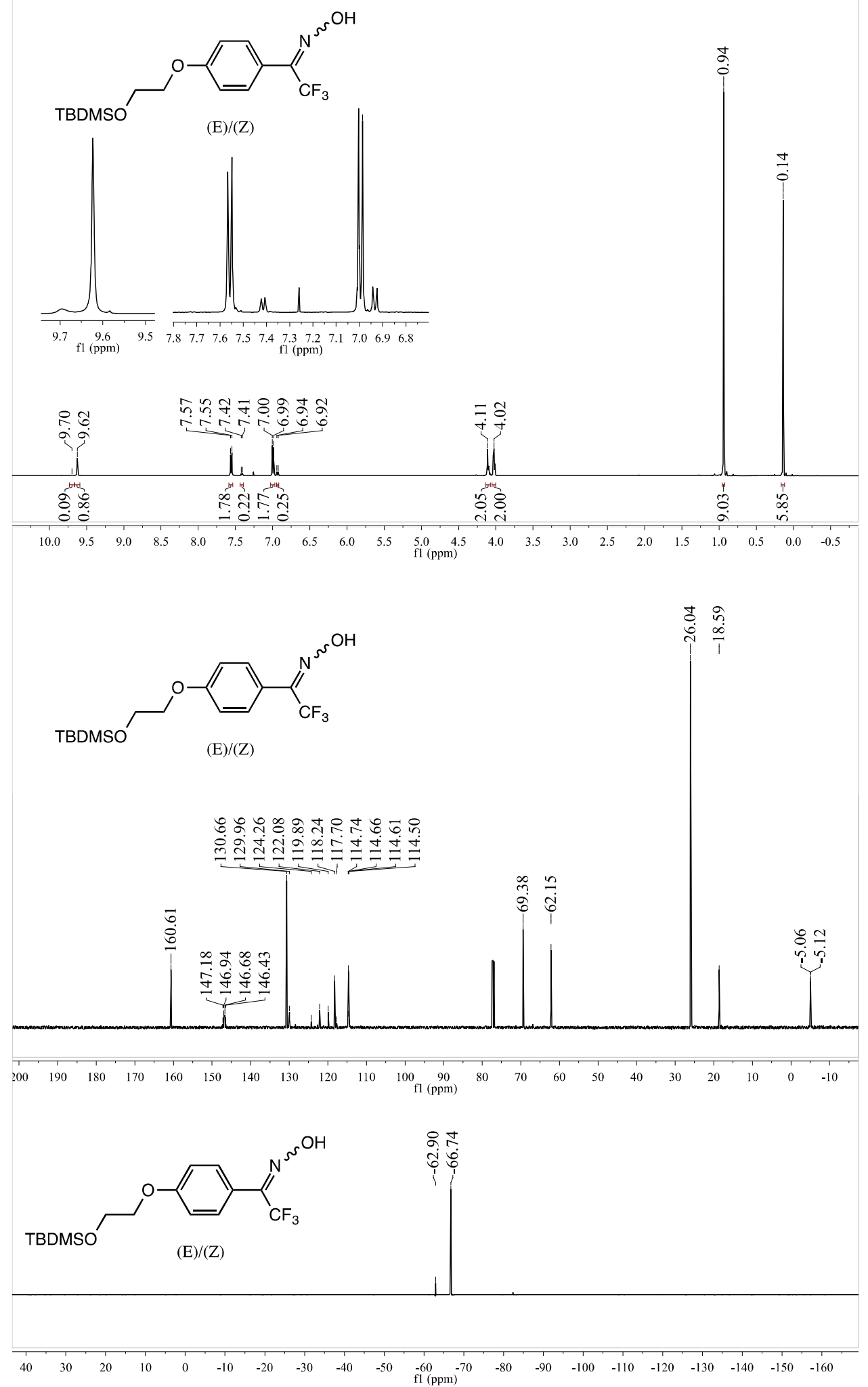

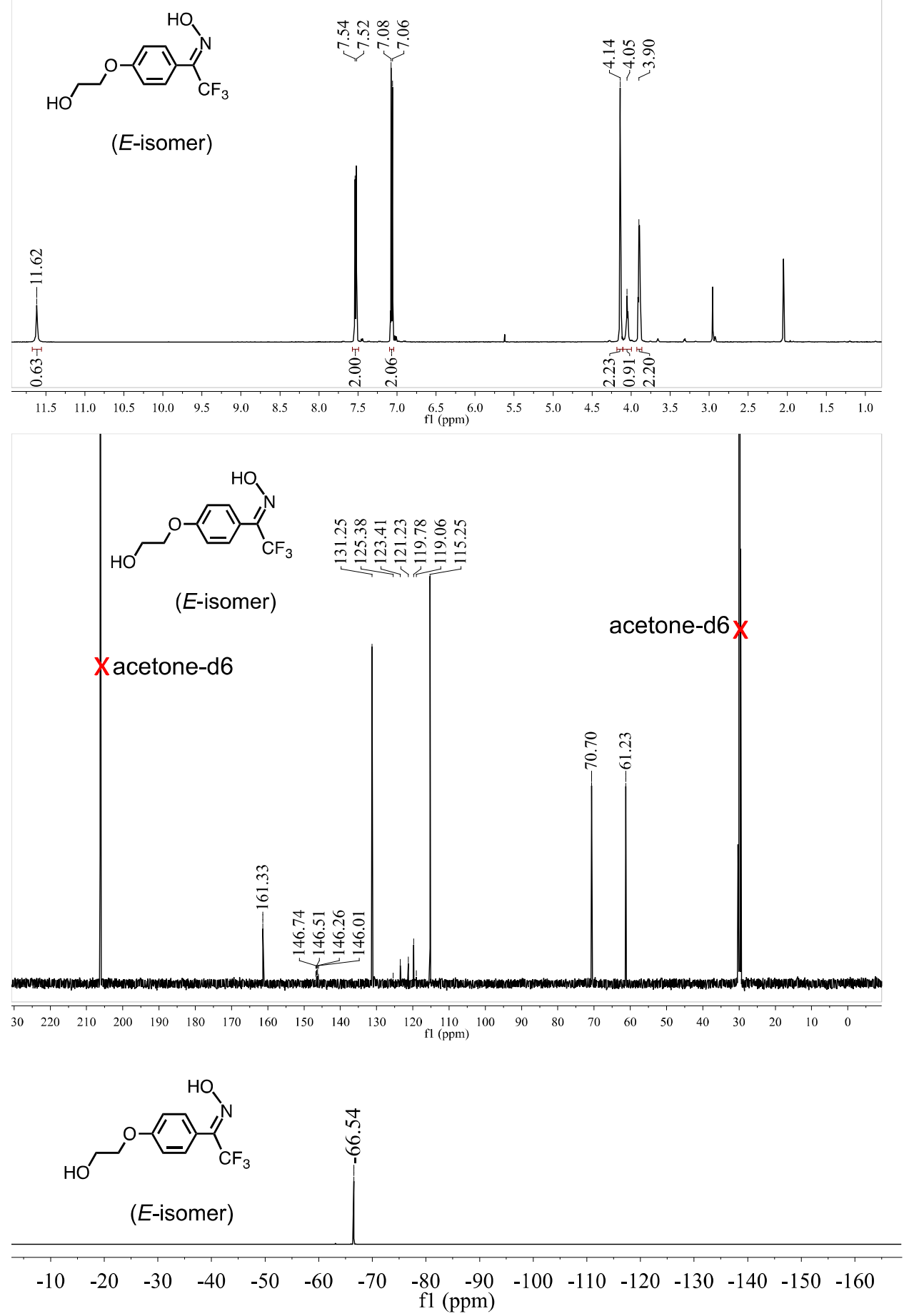

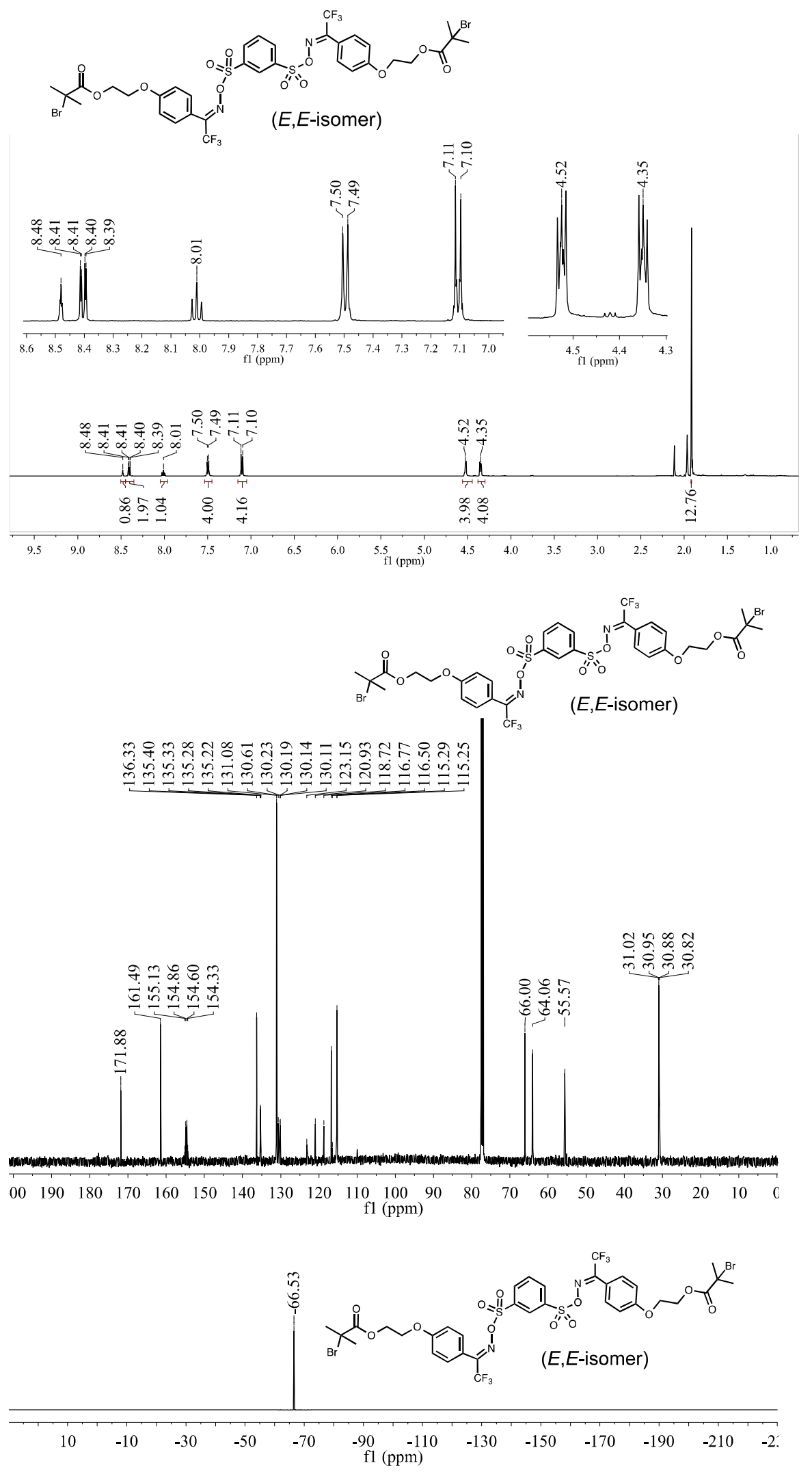

S23 

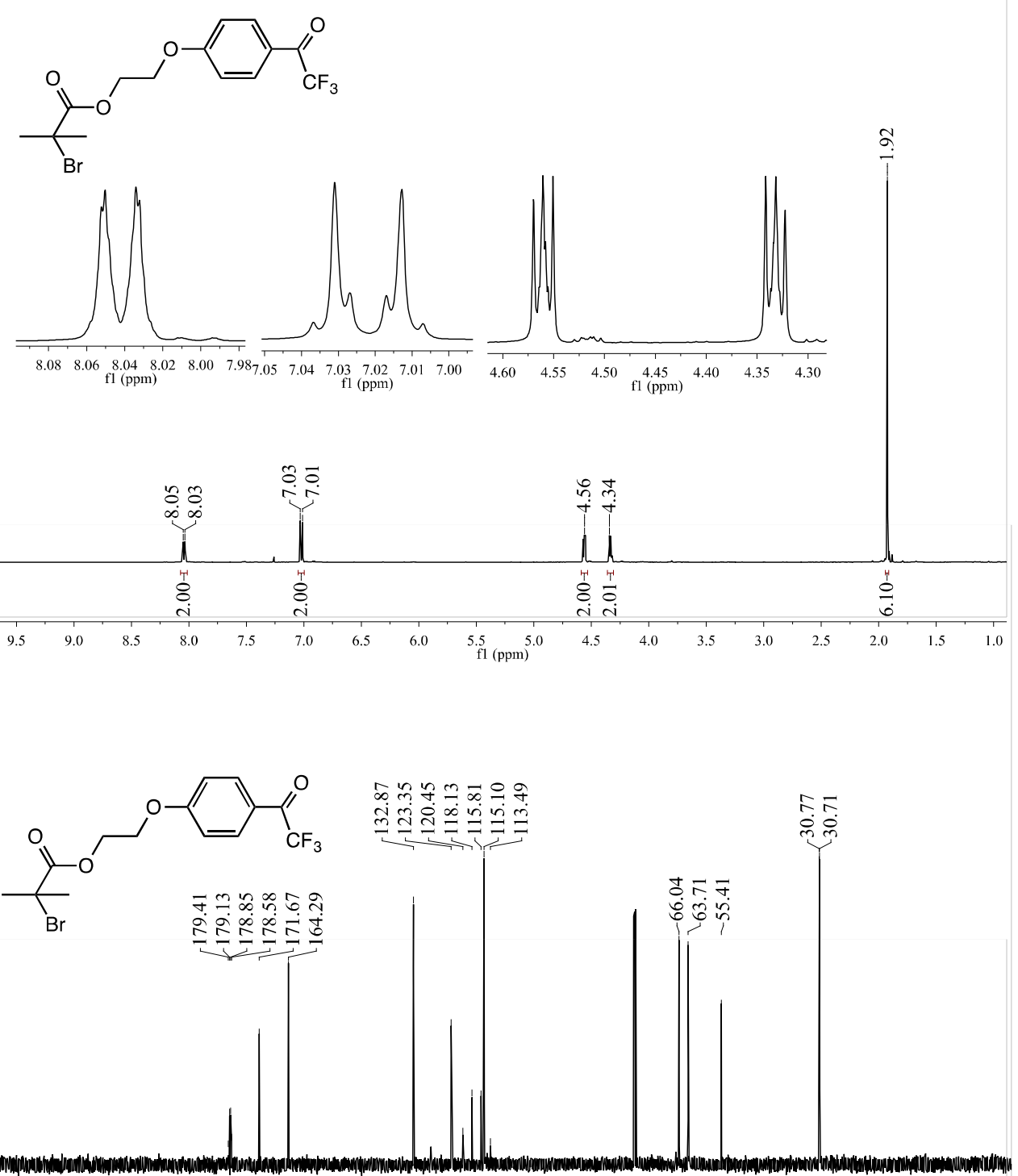

$\begin{array}{lllllllllllllllllllllllllllll}230 & 220 & 210 & 200 & 190 & 180 & 170 & 160 & 150 & 140 & 130 & 120 & 110 & 100 & 90 & 80 & 70 & 60 & 50 & 40 & 30 & 20 & 10 & 0 & -10\end{array}$

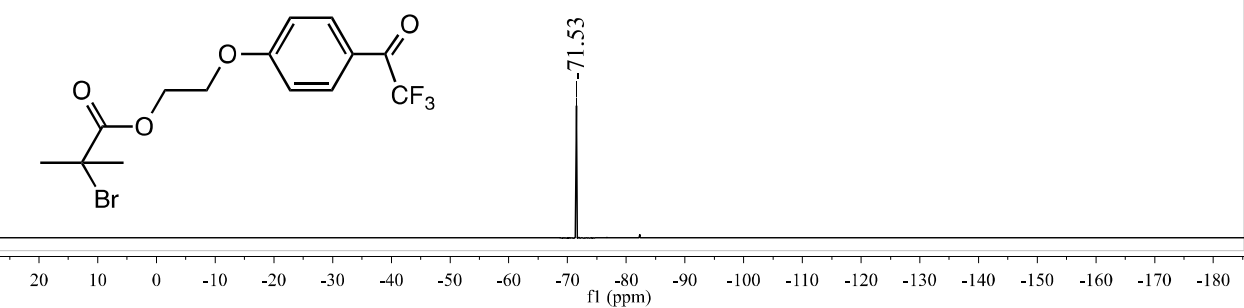



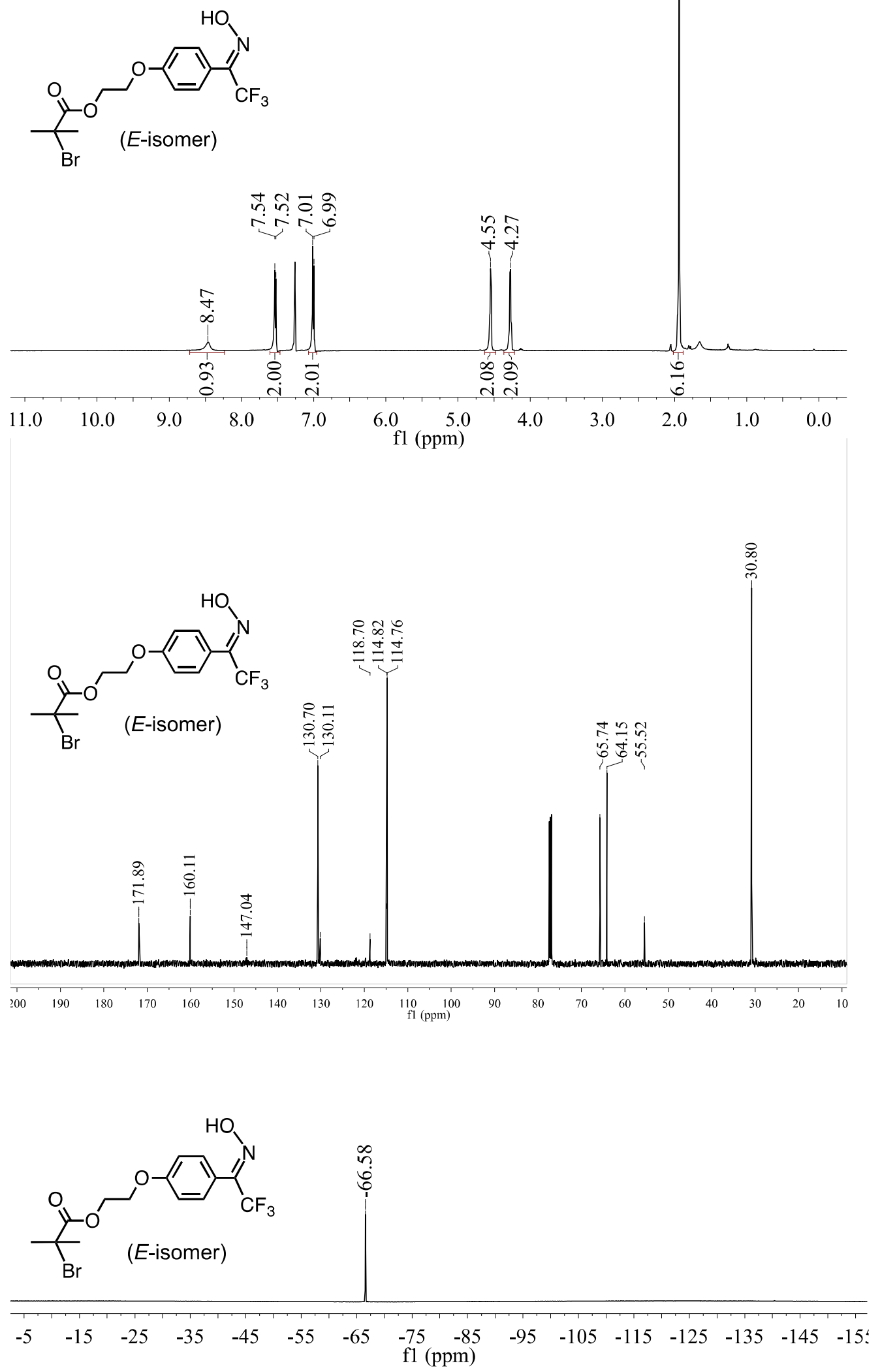


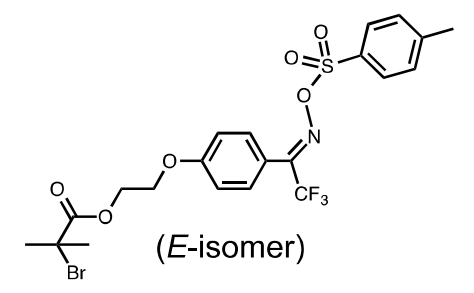

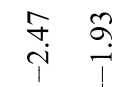
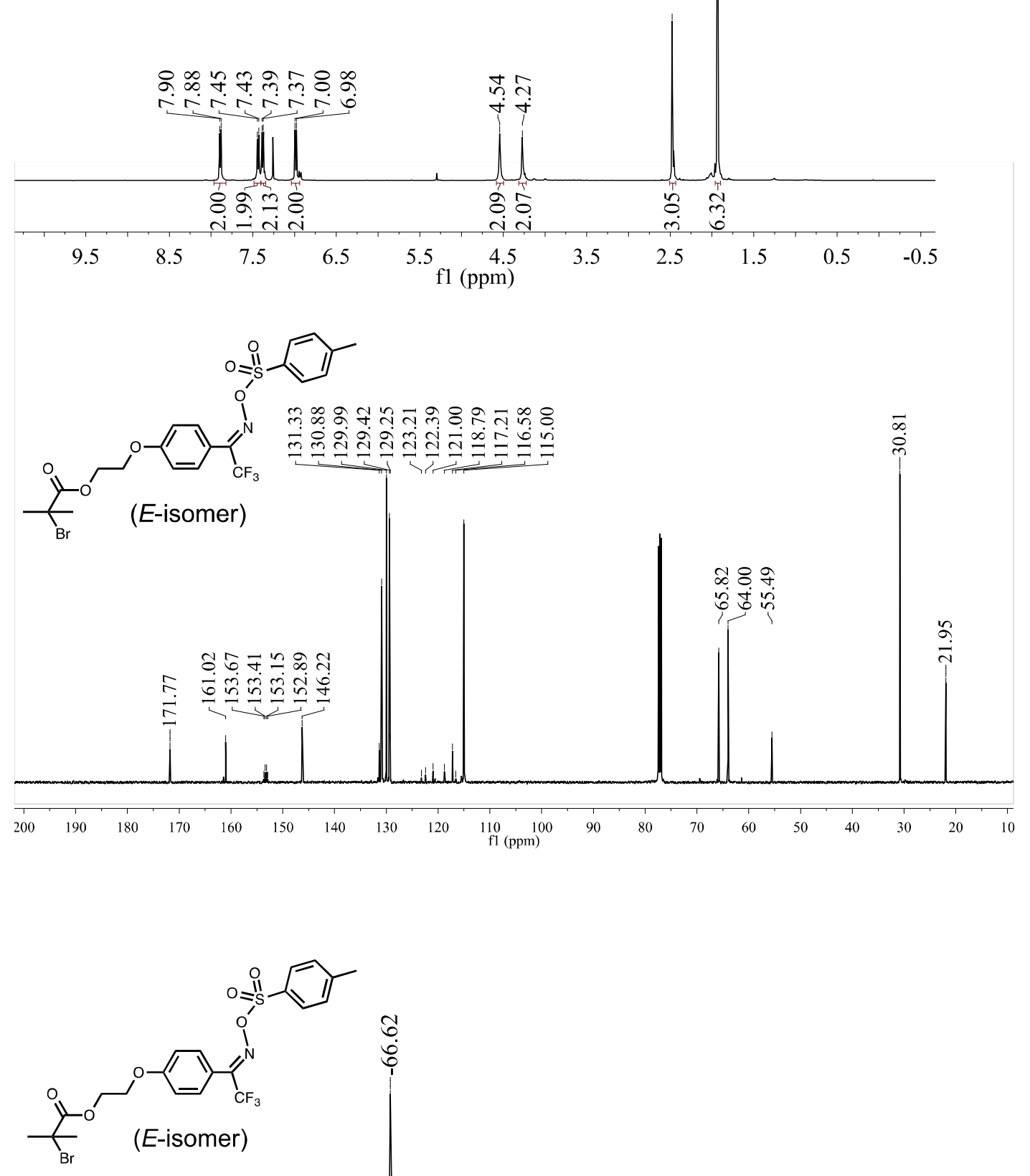

$\begin{array}{rrrrrrrrrrrrrrrr}-10 & -20 & -30 & -40 & -50 & -60 & -70 & -80 & -90 & -100 & -110 & -120 & -130 & -140 & -150 & -160\end{array}$ 

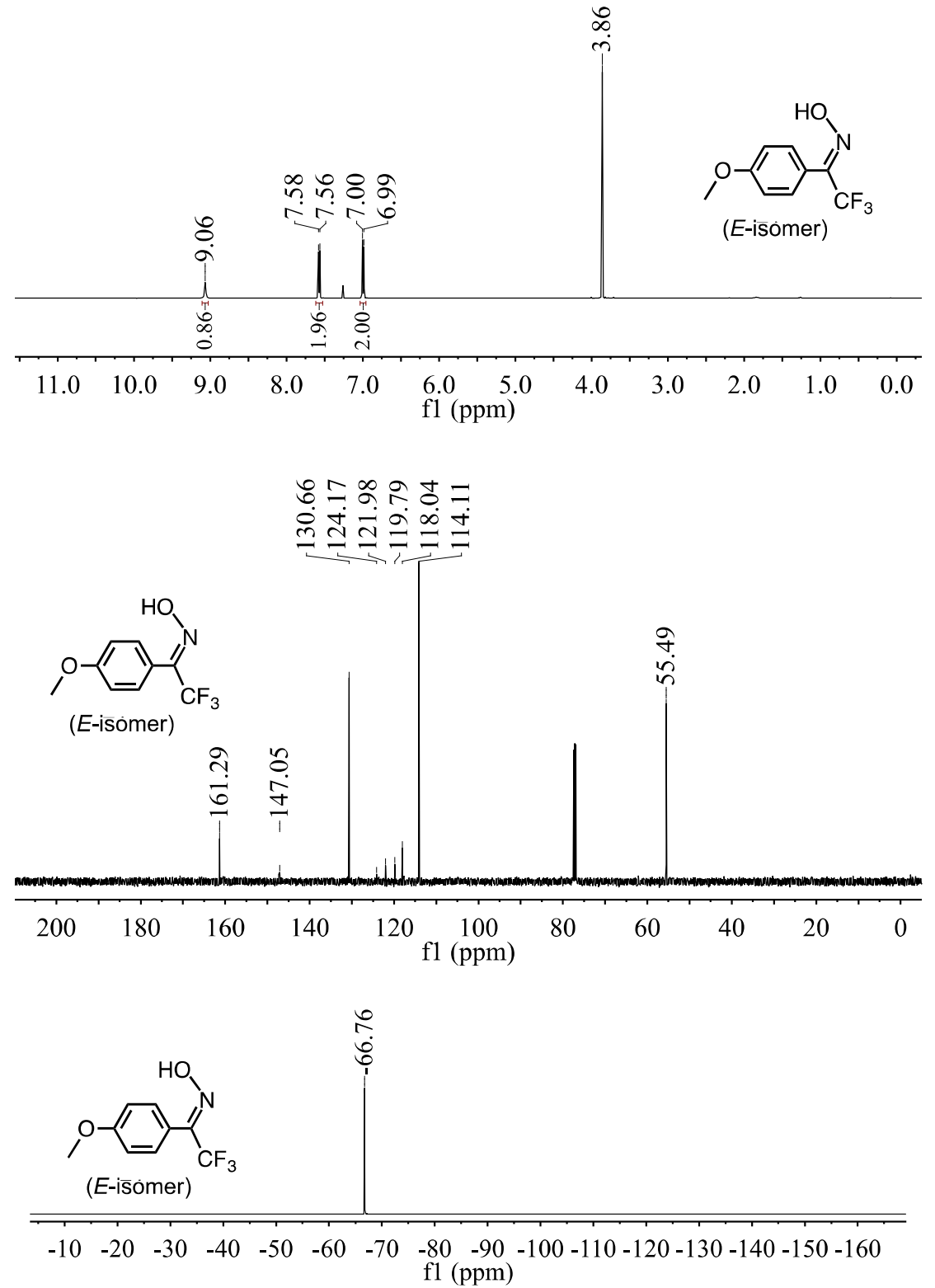

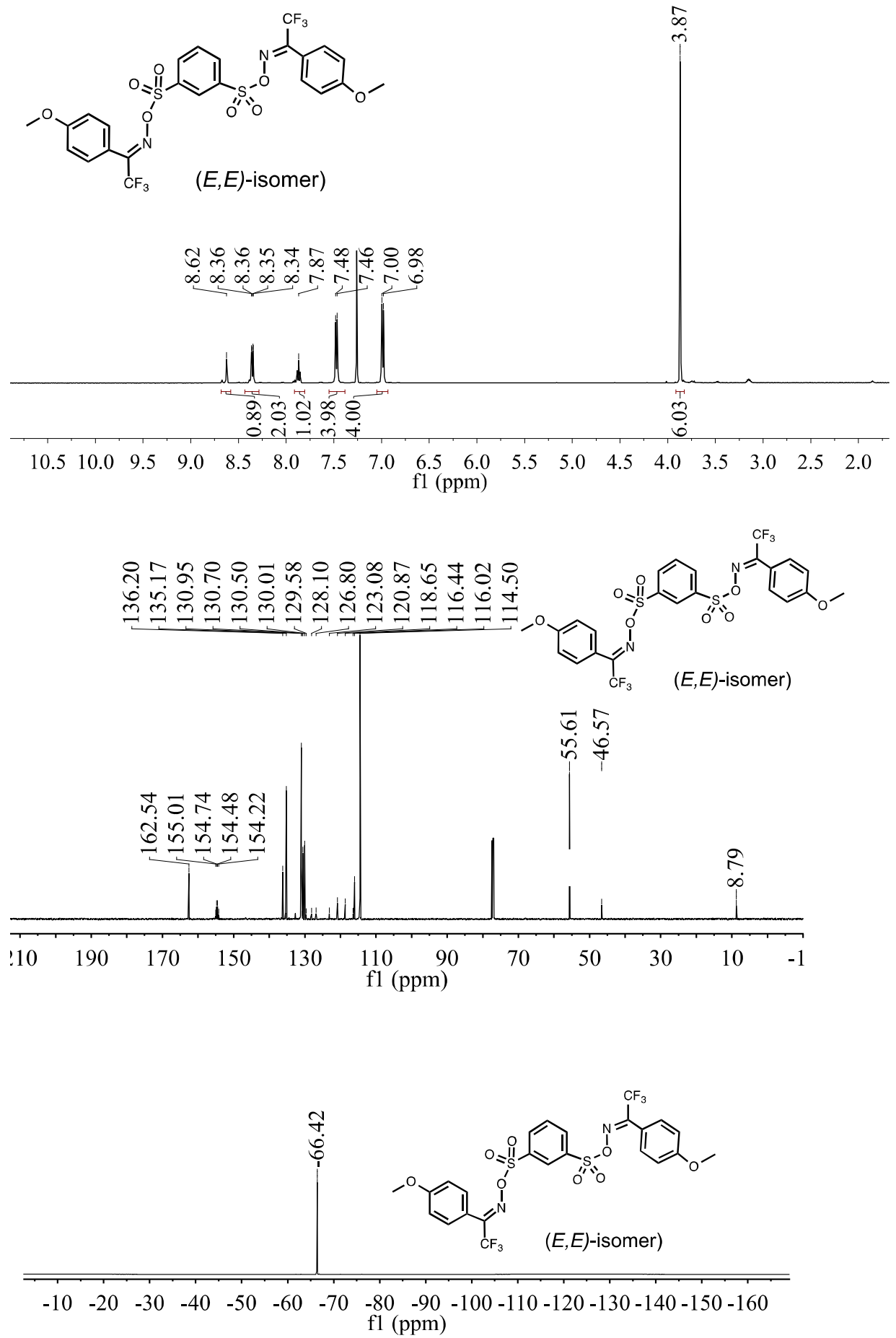

S28 


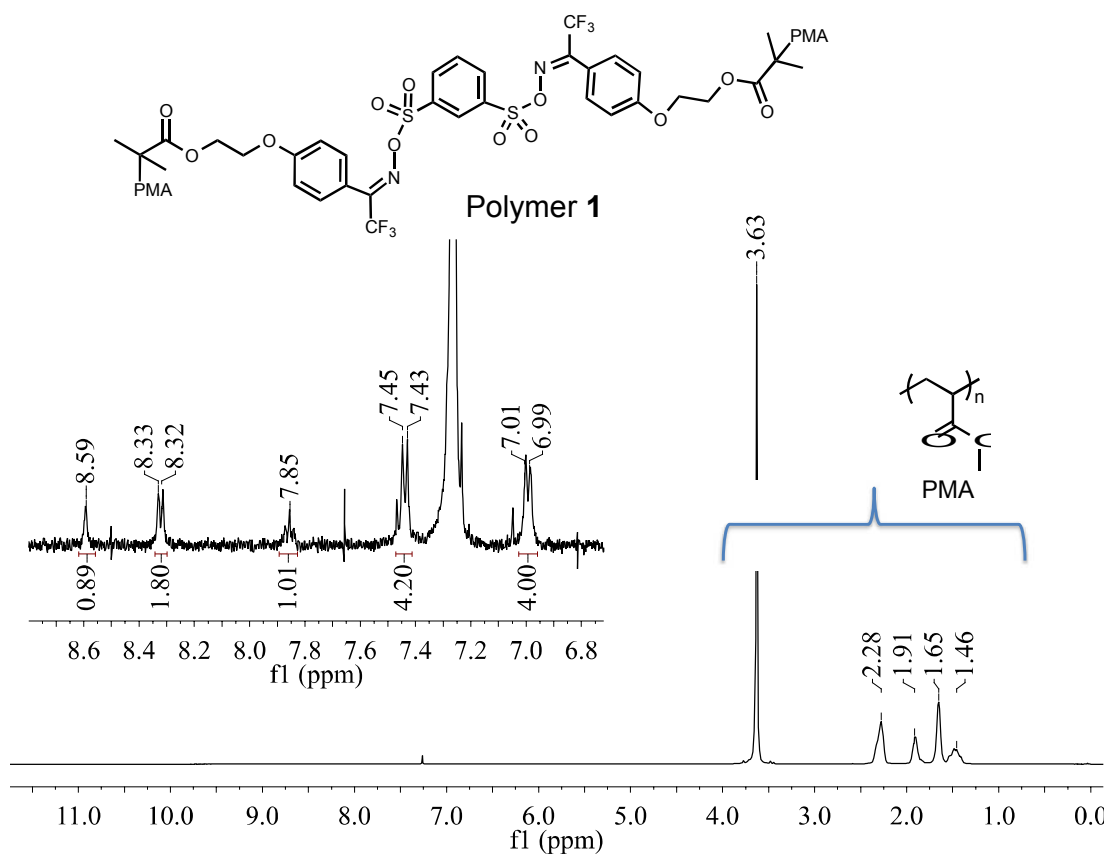

\subsection{References}

1. Beyer, M. K. J. Chem. Phys. 2000, 112, 7307-7312.

2. Davis, D. A.; Hamilton, A.; Yang, J.; Cremar, L. D.; Van Gough, D.; Potisek, S. L.; Ong, M. T.; Braun, P. V.; Martínez, T. J.; White, S. R.; Moore, J. S.; Sottos, N. R. Nature 2009, 459, 68-72.

3. Kryger, M. J.; Munaretto, A. M.; Moore, J. S. J. Am. Chem. Soc. 2011, 133, 18992-8998.

4. Diesendruck, C. E.; Zhu, L.; Moore, J. S. Chem. Commun. 2014, 50, 13235-13238.

5. Lu, X.; Cseh, S.; Byun, H. S.; Tigyi, G.; Bittman, R. J. Org. Chem. 2003, 68, 7046-7050.

6. Raimer, B.; Lindel, T. Chem. Eur. J. 2013, 19, 6551-6555. 